\title{
Microstructure And Strength Characteristics Of Alloy 617 Welds
}

T. C. Totemeier

H. Tian

D. E. Clark

J. A. Simpson

June 2005

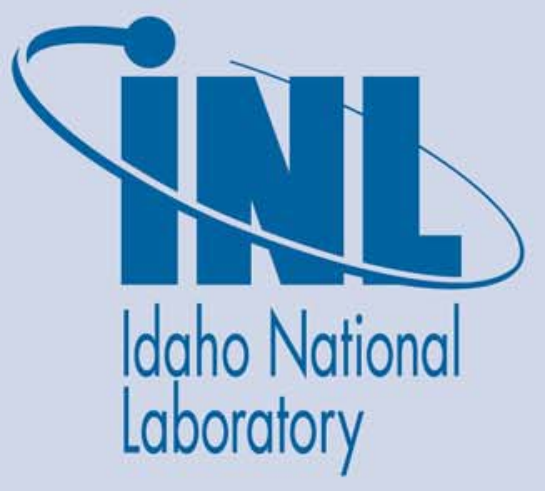

The INL is a U.S. Department of Energy National Laboratory operated by Battelle Energy Alliance 


\title{
Microstructure and Strength Characteristics of Alloy 617 Welds
}

\author{
T.C. Totemeier, H. Tian, D.E. Clark, and J.A. Simpson
}

June 2005

Idaho National Laboratory

Idaho Falls, Idaho 83415

Prepared for the

U.S. Department of Energy

Office of Nuclear Energy, Science and Technology

Under DOE Idaho Operations Office

Contract DE-AC07-05ID14517 


\section{Microstructure and Strength Characteristics of Alloy 617 Welds}

INL/EXT-05-00488

June 2005

Approved by

G.O. Hayner

Date

P.E. MacDonald

Date 


\section{ABSTRACT}

Three types of high-temperature joints were created from alloy 617 base metal: fusion welds, braze joints, and diffusion bonds. The microstructures of all joint types and tensile properties of fusion welds and braze joints were characterized. Sound fusion welds were created by the Gas-Tungsten Arc Weld (GTAW) process with alloy 617 filler wire. Cross-weld tensile strengths were equal to the parent metal at temperatures of 25,800 , and $1000^{\circ} \mathrm{C}$; ductilities of the joints were only slightly lower than that of the parent metal. Failure occurred in the weld fusion zone at room temperature and in the parent metal at elevated temperatures. Incomplete wetting occurred in joints produced by vacuum brazing using AWS BNi-1 braze alloy, believed to be due to tenacious $\mathrm{Al}$ and Ti oxide formation. Incompletely bonded butt joints showed relatively poor tensile properties. A second set of braze joints has been created with faying surfaces electroplated with pure Ni prior to brazing; characterization of these joints is in progress.

Conditions resulting in good diffusion bonds characterized by grain growth across the bondline and no porosity were determined: vacuum bonding at $1150^{\circ} \mathrm{C}$ for 3 hours with an initial uniaxial stress of 20 $\mathrm{MPa}$ (constant ram displacement). A $15 \mu \mathrm{m}$ thick pure Ni interlayer was needed to achieve grain growth across the bondline. Tensile testing of diffusion bonds is in progress. 



\section{ACKNOWLEDGMENTS}

The authors would like to acknowledge the assistance of R.J. Bitsoi with welding and T.C. Morris with metallography. 



\section{CONTENTS}

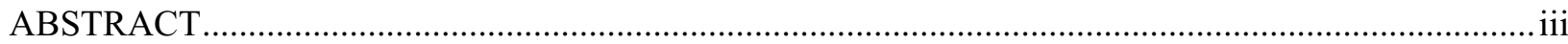

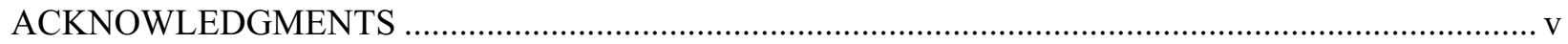

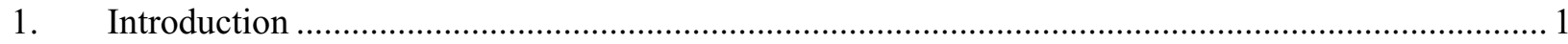

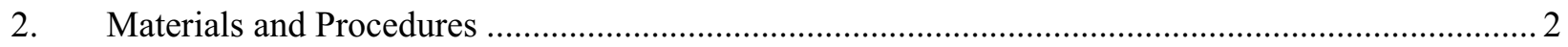

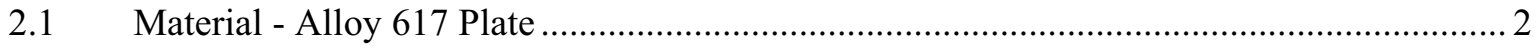

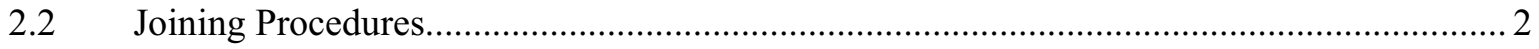

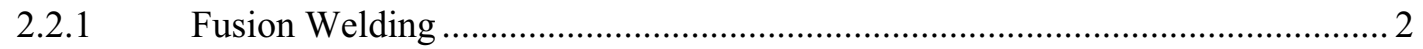

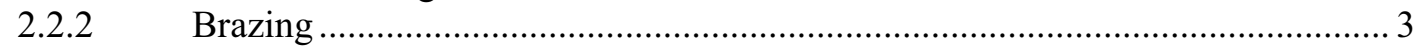

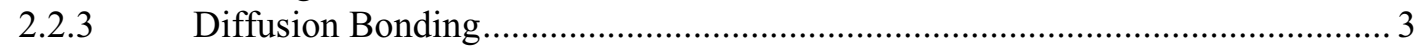

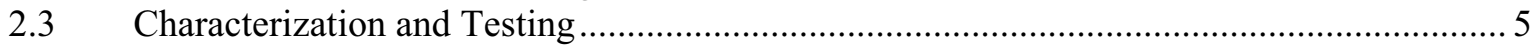

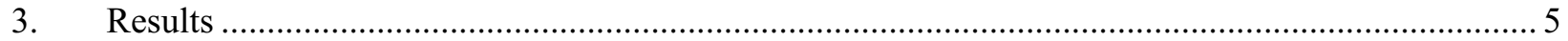

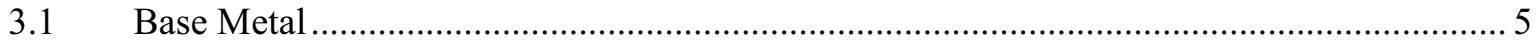

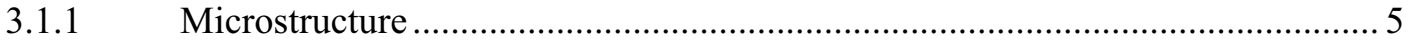

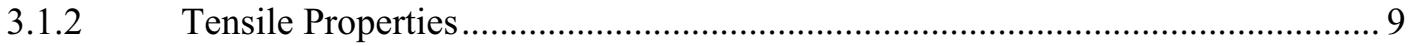

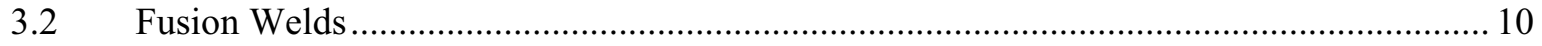

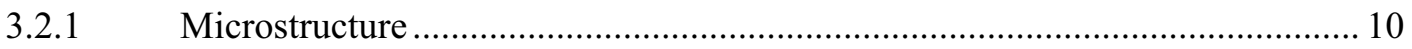

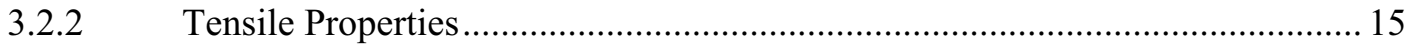

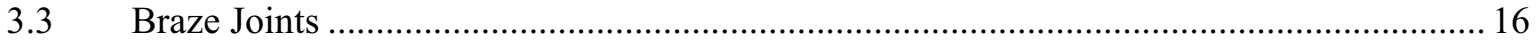

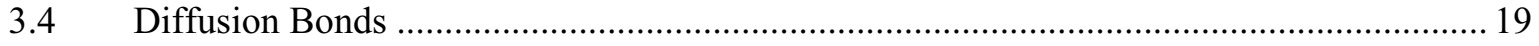

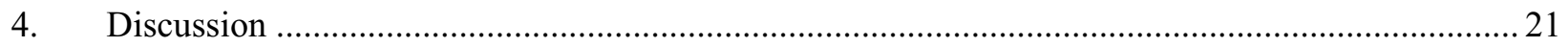

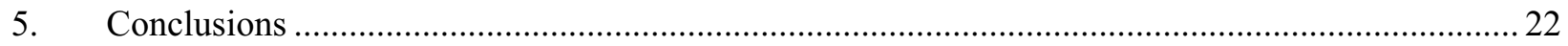

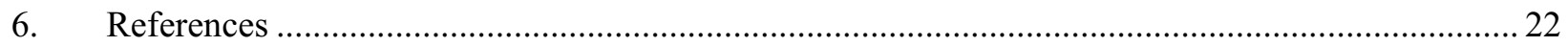




\section{FIGURES}

Figure 1. Fusion weld joint profile. Dimensions in inches.

Figure 2. Schematic of butt (left) and scarf (right) braze joints illustrating orientation of tensile specimens with respect to the joint. Dimensions in inches.

Figure 3. Typical stress decay during constant displacement diffusion bonding. Stress drop after 10,000 $\mathrm{sec}$ is due to removal of load at end of bond cycle.................................................................... 5

Figure 4. Three-dimensional montage of standard chemistry alloy 617 microstructure (3/4 inch plate)... 6

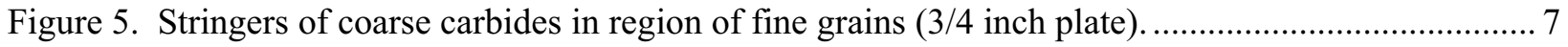

Figure 6. Microstructure of $1 / 2$ inch plate (section normal to long transverse direction).......................... 7

Figure 7. Secondary (a) and backscattered (b) electron images of carbides in the $3 / 4$ inch plate. ............... 8

Figure 8. Secondary (a) and backscattered (b) electron images of carbides in the $1 / 2$ inch plate. ............... 9

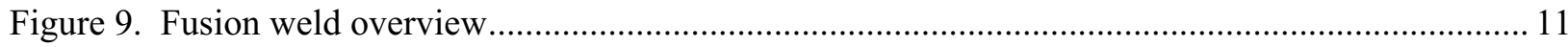

Figure 11. Typical fusion zone microstructures showing large columnar grains and dendritic structure.. 12

Figure 12. Close view of fusion zone microstructure showing second-phase particles along grain boundaries and in interdendritic regions.

Figure 13. Typical area of fine recrystallized grains in the center of the weld fusion zone.

Figure 14. Overview of fusion zone - HAZ - base metal area.

Figure 15. Close view of HAZ.

Figure 16. Polished and etched section of a cross-weld specimen tensile tested at room temperature.

Weld fusion zone (bright) and fracture surface are on the right.

Figure 17. Polished and etched section of a cross-weld specimen tensile tested at $800^{\circ} \mathrm{C}$ at a strain rate of $3 \times 10^{-3} \mathrm{sec}^{-1}$. Weld fusion zone (bright) is in the center, fracture surface in the parent metal is on the right

Figure 18. Polished and etched section of a cross-weld specimen tensile tested at $1000^{\circ} \mathrm{C}$ at a strain rate of $3 \times 10^{-3} \mathrm{sec}^{-1}$. Weld fusion zone (bright) is in the center, fracture surface in the parent metal is on the right.....

Figure 19. Mating halves of a braze scarf joint tensile specimen blank that failed along the bond.

Figure 20. Etched metallographic cross-section of incomplete bond area. Wetted half of joint is on bottom, non-wetted half on top.

Figure 21. Etched metallographic cross-section of well-bonded area of braze joint. 18 
Figure 22. Fracture surface of incompletely-bonded braze joint tensile specimen tested at room temperature.

Figure 23. Etched cross-section of diffusion bond created at $1150^{\circ} \mathrm{C}$ and $3.5 \mathrm{MPa}$ with a 3 hour hold time and a $15 \mu \mathrm{m}$ thick Ni interlayer. Gaps are still present along the bondline.....

Figure 24. Etched cross-section of diffusion bond created at $1120^{\circ} \mathrm{C}$ and $15 \mathrm{MPa}$ initial stress (displacement control) with a 3 hour hold time and a $15 \mu \mathrm{m}$ thick Ni interlayer. Complete bonding with grain growth across the bondline was achieved.

Figure 25. Etched cross-section of diffusion bond created at $1120^{\circ} \mathrm{C}$ and $15 \mathrm{MPa}$ initial stress (displacement control) with a 3 hour hold time and no interlayer. Complete bonding occurred but grain growth across the bondline did not occur.

Figure 26. Example of incomplete bond area in diffusion bond created at $1150^{\circ} \mathrm{C}$ and $20 \mathrm{MPa}$ initial stress (displacement control) with a 2 hour hold time and $15 \mu \mathrm{m}$ Ni interlayer.

\section{TABLES}

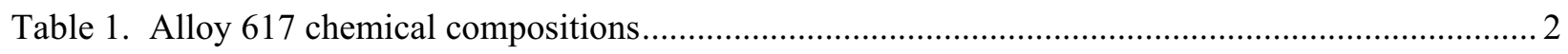

Table 2: Diffusion bonding conditions and results ......................................................................... 4

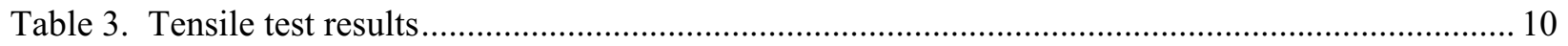




\section{Microstructure and Strength Characteristics of Alloy 617 Welds}

\section{Introduction}

The Next Generation Nuclear Plant (NGNP) is being designed as a helium-cooled, graphitemoderated, thermal neutron spectrum nuclear reactor for the demonstration of thermodynamically efficient production of electricity and hydrogen without production of greenhouse gases. For efficient production of hydrogen using a thermochemical cycle driven by nuclear process heat the reactor coolant outlet temperature must be as high as reasonably achievable, ideally in excess of $950^{\circ} \mathrm{C}$. Such temperatures will significantly challenge the temperature capability of existing materials of construction, particularly for metallic materials directly exposed to the coolant.

The intermediate heat exchanger (IHX) will perform a critical function in the operation of the NGNP for both direct and indirect cycle applications, transferring heat from the primary reactor helium to a secondary working fluid at a slightly lower temperature. The total operating pressure of the IHX under normal conditions is anticipated to be $7-8 \mathrm{MPa}$, with a small $(0.1 \mathrm{MPa})$ pressure differential between the primary and secondary legs. Loss of pressure in the secondary leg under off-normal or accident conditions would lead to a full 7-8 MPa pressure drop across the IHX. Current designs call for a compact IHX, with printed circuit, brazed plate-and-fin, and ceramic open-cell foam types suggested. More traditional designs may need to be considered as a backup. High-temperature joints will be a key element of all designs. ${ }^{[1]}$

High-temperature metallic alloys are the primary candidate materials for the IHX and other components anticipated to operate at temperatures between 800 and $1000^{\circ} \mathrm{C}$. Several existing alloys, e.g. nickel-base alloys 617, 230, and X, are approved for non-nuclear construction under Section VIII of the American Society of Mechanical Engineers (ASME) boiler and pressure vessel design code, but none are approved for construction under the nuclear construction requirements in Section III. A draft code case was developed for alloy 617 in the 1980's, but the final approval process was not completed. The main data needs identified in review of the draft case include weldment fatigue data, a more complete creepfatigue database, and a better understanding of the synergistic effects of aging, environment, loading, and temperature. ${ }^{[2,3]}$

Activities at the Idaho National Laboratory (INL) under the high temperature design methodology (HTDM) task of the NGNP materials research and development program are focused on addressing the needs cited above for candidate high-temperature alloys, particularly improved understanding of creepfatigue-environment interactions in candidate high-temperature alloys and joints made from them. Initial work is being performed on alloy 617 due to the fact that it appears to be closest to gaining code approval in Section III, but research is also planned on other alloys.

The first task in the study of creep-fatigue-environment interactions in alloy 617 base metal and joints is the production and characterization of joints prior to creep-fatigue testing. This report presents the results of initial microstructural and mechanical characterization of three types of high temperature alloy 617 joints: fusion welds, high-temperature braze joints, and diffusion bonds. In the absence of an IHX design, the joints produced and studied in this program are "typical" for the alloy, i.e., joining parameters are those commonly used in industry and dimensions are those convenient for production of test specimens. It is recognized that overall joint behavior is system and geometry dependent; the joints tested were designed for ease of interpretation of fundamental mechanical and environmental degradation mechanisms. 
Also included in this report is characterization of the baseline microstructure and properties for the material used to produce the joints-alloy 617 produced to standard ASTM/ASME material specifications.

\section{Materials and Procedures}

\subsection{Material - Alloy 617 Plate}

Two alloy 617 plates were procured $-\mathrm{a} 1 / 2$ inch thick plate produced by Haynes International (Kokomo, IN) and a $3 / 4$ inch thick plate produced by Special Metals Corporation (Huntington, WV). The $1 / 2$ inch plate was $12 \times 12$ inches square; the $3 / 4$ inch plate was $48 \times 48$ inches square. The smaller plate was used for initial tensile testing and environmental exposure evaluation during the period that the larger plate was being procured, and subsequently for production of specimen blanks for diffusion bonding trials. The larger plate was used for production of fusion welds and braze joints. Both plates were supplied as meeting the ASTM B 168-01 specification. Chemical compositions for the two plates as supplied by the manufacturers are given in Table 1 .

Table 1. Alloy 617 chemical compositions

\begin{tabular}{|c|c|c|c|c|c|c|c|c|c|c|c|c|c|}
\hline \multirow{2}{*}{ Material } & \multirow{2}{*}{ Heat Number } & \multicolumn{12}{|c|}{ Composition (wt.\%) } \\
\hline & & $\mathrm{Ni}$ & $\mathrm{Cr}$ & Co & Mo & $\mathrm{Fe}$ & $\mathrm{Al}$ & $\mathrm{Ti}$ & $\mathrm{C}$ & $\mathrm{Mn}$ & $\mathrm{Si}$ & $\mathrm{S}$ & $\mathrm{B}$ \\
\hline Haynes $1 / 2$ " plate & 861738810 & Bal. & 21.99 & 12.24 & 9.60 & 1.06 & 1.09 & 0.44 & 0.08 & 0.03 & 0.08 & 0.002 & 0.003 \\
\hline Special Metals $3 / 4$ " plate & XX2834UK & Bal. & 21.91 & 11.42 & 9.78 & 1.69 & 0.96 & 0.34 & 0.08 & 0.11 & 0.12 & 0.001 & 0.002 \\
\hline
\end{tabular}

\subsection{Joining Procedures}

\subsubsection{Fusion Welding}

Two multi-pass fusion welds were made in the $3 / 4$ inch plate using the gas-tungsten arc weld (GTAW) process. Alloy 617 filler wire 0.045 inch in diameter was used. The weld geometry is shown in Figure 1; the welds were butt type with a J-groove profile. The bevel angle of the J-groove face was small $\left(10^{\circ}\right)$ to minimize the variation of the weldment width with position through the thickness of the plate. The welds were completed in six passes with air intercooling to at least $150^{\circ} \mathrm{C}$ between passes. Interpass temperature was measured by a thermocouple attached to the welded plate.

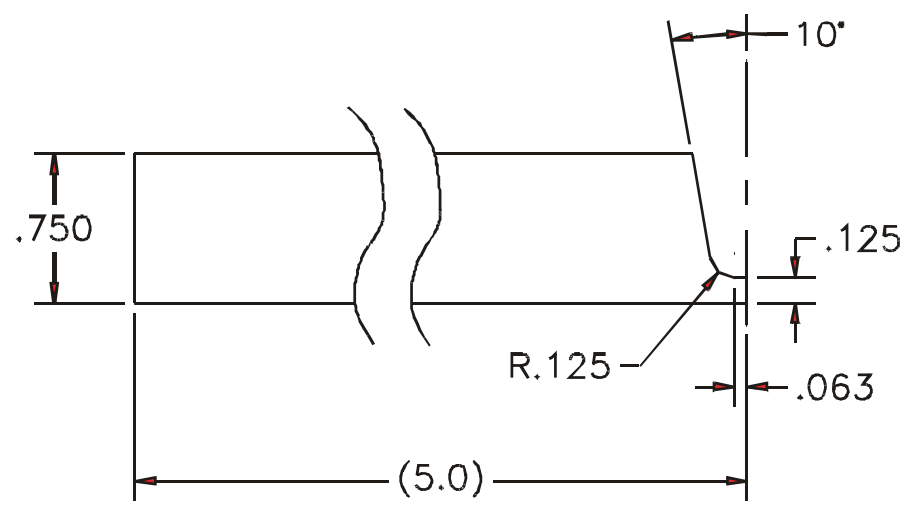

Figure 1. Fusion weld joint profile. Dimensions in inches. 


\subsubsection{Brazing}

Two joint geometries were made using the high-temperature braze, a simple butt joint and a $45^{\circ}$ scarf joint (butt joint inclined to the tensile axis, Figure 2). The two joints were selected to study the differences in behavior between pure tensile stresses across a butt joint and predominantly shear stresses produced across a scarf joint when the joints have been machined into cylindrical cross-joint tensile and creep-fatigue specimens with the long axis of the specimen in line with the longitudinal orientation in the source plate. Two sizes of joined plates were created: 9 inch total width for machining into creep-fatigue specimens and 4.25 inch total width for machining into tensile specimens. The smaller plates are depicted in Figure 2; the joint geometry for the larger plates is essentially identical.

Wall Colmonoy Corporation (Dayton, $\mathrm{OH}$ ) was contracted to perform the brazing operation. The joints were prepared by machining the faying surfaces to a 16 microinch surface finish and grit blasting with pure Ni powder to remove surface oxides. The plates were tack welded on the corners to produce a joint gap of approximately $0.1 \mathrm{~mm}$. The brazing alloy was American Welding Society (AWS) grade BNi-1 (Ni-14Cr-4.5Fe-4.5Si-3B, wt.\%). Brazing was performed in vacuum for 3 hours at $1175^{\circ} \mathrm{C}$. Note that the re-melt temperature of the braze is well above $1000^{\circ} \mathrm{C}$ due to the diffusion of the melting point depressants $\mathrm{Si}$ and $\mathrm{B}$ into the base metal during the braze operation.
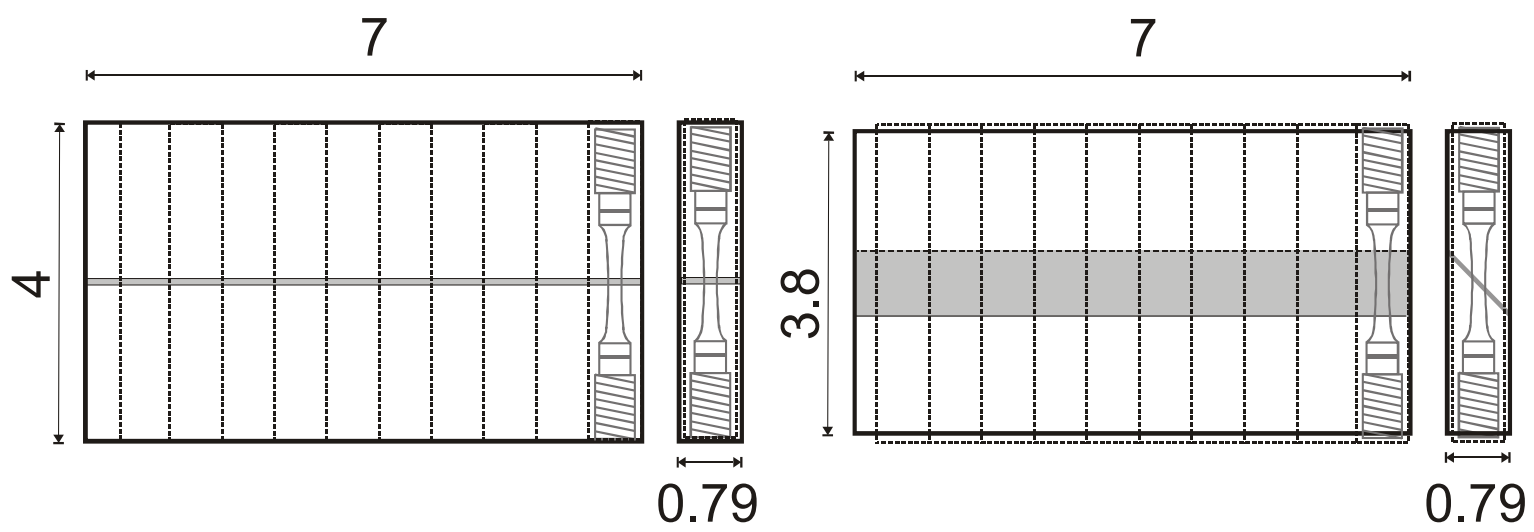

Figure 2. Schematic of butt (left) and scarf (right) braze joints illustrating orientation of tensile specimens with respect to the joint. Dimensions in inches.

\subsubsection{Diffusion Bonding}

Diffusion bonds were created using 0.5 inch diameter cylindrical test blanks in a Gleeble ${ }^{\circledR}$ thermomechanical weld simulator (Dynamic Systems, Inc., Poestenkill, NY). With the exception of the final two, all test blanks were machined from the $1 / 2$ inch plate. Table 2 lists bonding conditions and results for trial bonds created to date. The faying surfaces were machined to a 16 microinch finish. Bonding was performed in high vacuum $\left(\sim 10^{-5}\right.$ Torr $)$ at temperatures of 1120 and $1150^{\circ} \mathrm{C}$ with hold times of 2 or 3 hours. A $15 \mu \mathrm{m}$ thick pure Ni interlayer was used for some bonds. The first set of bonds were created with a constant uniaxial stress applied perpendicular to the bond surfaces; for later bonds a constant initial displacement was used. In the latter case the force across the interface relaxed with time, as shown in Figure 3 for bonds created with an initial stress of $\sim 18 \mathrm{MPa}$. Use of constant displacement allowed high initial stress and displacement to close bondline gaps without excessive overall deformation that would result from high stress throughout the bond cycle. 
Table 2: Diffusion bonding conditions and results

\begin{tabular}{|c|c|c|c|c|c|}
\hline \multirow[b]{2}{*}{ Specimen ID } & \multirow[b]{2}{*}{ Interlayer } & \multicolumn{3}{|c|}{ Bond Conditions } & \multirow[b]{2}{*}{ Result and Notes } \\
\hline & & $\begin{array}{l}\text { Temperature } \\
\left({ }^{\circ} \mathrm{C}\right) \\
\end{array}$ & $\begin{array}{l}\text { Stress } \\
(\mathrm{MPa}) \\
\end{array}$ & $\begin{array}{l}\text { Hold Time } \\
(\mathrm{hr})\end{array}$ & \\
\hline IN617-DIFF-01 & $15 \mu \mathrm{m}$ Ni Foil & $1120(?)$ & 3.5 & 3 & $\begin{array}{l}\text { Temp excursion produced barreling and cavitation } \\
\text { in radial direction, otherwise good bond. }\end{array}$ \\
\hline IN617-DIFF-02 & $15 \mu \mathrm{m}$ Ni Foil & 1150 & 3.5 & 3 & $\begin{array}{l}\text { Some contact and grain growth across interface, but } \\
\text { far from full bonding. Noticeable increase in grain } \\
\text { size in heated area. }\end{array}$ \\
\hline IN617-DIFF-03 & $15 \mu \mathrm{m}$ Ni Foil & 1120 & 3.5 & 3 & $\begin{array}{l}\text { Faying surfaces slightly misaligned - gap on one } \\
\text { side, other side is better bonded than DIFF- } 02 \text { but } \\
\text { not complete. }\end{array}$ \\
\hline IN617-DIFF-04 & None & 1120 & $15 \rightarrow 5^{*}$ & 3 & $\begin{array}{l}\text { Good bond, no porosity, good match-up of faying } \\
\text { surfaces, but no grain growth across bondline. }\end{array}$ \\
\hline IN617-DIFF-05 & $15 \mu \mathrm{m}$ Ni Foil & 1120 & $15 \rightarrow 5^{*}$ & 3 & $\begin{array}{l}\text { Good bond, nickel layer appears to polish/etch } \\
\text { strongly, looks like a groove. Grain growth across } \\
\text { bondline, more so in center than edges. }\end{array}$ \\
\hline IN617-DIFF-06 & None & 1150 & $15 \rightarrow 5^{*}$ & 3 & $\begin{array}{l}\text { Good bond, no porosity, good match-up of faying } \\
\text { surfaces, but generally no grain growth across } \\
\text { bondline, except for one edge. Grain size } \\
\text { noticeably increased relative to } 1120^{\circ} \mathrm{C} \text { exposure. }\end{array}$ \\
\hline IN617-DIFF-07 & $15 \mu \mathrm{m}$ Ni Foil & 1150 & $15 \rightarrow 5^{*}$ & 3 & $\begin{array}{l}\text { Similar to DIFF- } 05 \text { - good grain growth across } \\
\text { bondline in some places (center), less along one } \\
\text { edge. }\end{array}$ \\
\hline IN617-DIFF-08 & $15 \mu \mathrm{m}$ Ni Foil & 1120 & $20 \rightarrow 7^{*}$ & 2 & $\begin{array}{l}\text { Partial bond - two areas of gap. Nickel layer } \\
\text { etches/polishes strongly - more so than previous } \\
\text { specimens. Particles on mating surfaces. Grain } \\
\text { growth across bond. }\end{array}$ \\
\hline IN617-DIFF-09 & $15 \mu \mathrm{m}$ Ni Foil & 1150 & $20 \rightarrow 7^{*}$ & 2 & $\begin{array}{l}\text { Good bond, one small area of gap. Grain growth } \\
\text { across bondline. Nickel layer polished/etched more } \\
\text { strongly than } 3 \text { hr hold, also observe particles along } \\
\text { mating surfaces. }\end{array}$ \\
\hline IN617-DIFF-10 & $15 \mu \mathrm{m}$ Ni Foil & 1120 & $20 \rightarrow 7^{*}$ & 3 & $\begin{array}{l}3 / 4 \text { inch plate. Good bond, grain growth across } \\
\text { bondline. }\end{array}$ \\
\hline IN617-DIFF-11 & $15 \mu \mathrm{m}$ Ni Foil & 1150 & $20 \rightarrow 7^{*}$ & 3 & $\begin{array}{l}3 / 4 \text { inch plate. Good bond, grain growth across } \\
\text { bondline. }\end{array}$ \\
\hline
\end{tabular}

\footnotetext{
* Bonding performed with constant displacement instead of constant stress. Stress relaxes with time.
} 


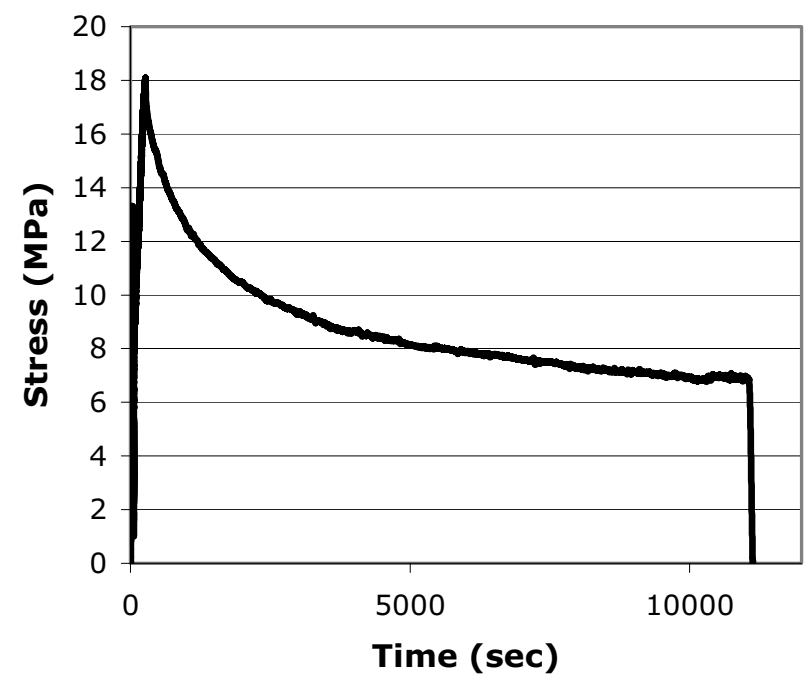

Figure 3. Typical stress decay during constant displacement diffusion bonding. Stress drop after 10,000 $\mathrm{sec}$ is due to removal of load at end of bond cycle.

\subsection{Characterization and Testing}

Standard metallographic procedures were used to prepare cross-sections of the base metals and joints for microstructural characterization. Sections were immersion etched in aqua regia $\left(25 \% \mathrm{HNO}_{3}\right.$, $75 \% \mathrm{HCl}$ ) for $\sim 20 \mathrm{sec}$ at room temperature. Scanning electron microscopy (SEM) with energy-dispersive $\mathrm{X}$-ray spectroscopy (EDS) was performed on selected samples to determine the composition of second phase particles.

Tensile testing was performed at room and elevated temperature using screw-driven universal testing machines. Specimens were cylindrical with either 4.2 or $6.4 \mathrm{~mm}$ gage diameter and 17 or $38 \mathrm{~mm}$ reduced section length. Tests were performed at a constant cross-head displacement rate to give an initial strain rate of $1 \times 10^{-3}$ or $3 \times 10^{-3} \mathrm{sec}^{-1}$. Specimen extension in room-temperature tests was measured using a standard clip gage. An averaging, rod-in-tube type extensometer was used for tests at elevated temperatures; the translated displacement was measured outside the furnace using two clip gages. The specimens were heated with a radiant furnace and allowed to equilibrate for 15 to 30 minutes prior to testing; specimen temperature was controlled with a type-K thermocouple to within $1{ }^{\circ} \mathrm{C}$. Tested specimens were examined using a light microscope; polished and etched metallographic cross-sections of selected specimens were also examined.

\section{Results}

\subsection{Base Metal}

\subsubsection{Microstructure}

The microstructure of the alloy 617 base metal strongly reflects the mechanical work required to produce the plate form. Stringers of relatively coarse carbides are aligned in the rolling direction for both the $1 / 2$ and $3 / 4$ inch plates. Figure 4 is a "three-dimensional" montage of the etched microstructure of the $3 / 4$ inch plate, clearly showing bands of stringers and associated coarse and fine grains. Grains in the coarse 
bands are approximately $100 \mu \mathrm{m}$ in diameter, while the finer grains range from approximately 10 to $30 \mu \mathrm{m}$. The fine-grained areas are associated with the carbide stringers, as shown in Figure 5. While similar carbide stringers were observed, the grain structure in the $1 / 2$ inch plate (shown in Figure 6 ) was not as banded as in the $3 / 4$ inch plate.

SEM examination confirmed the carbide nature of the stringer particles. Figure 7 shows secondary and backscattered electron images of the $3 / 4$ inch plate microstructure. The smaller, rounded particles are either Mo-rich (lighter in the backscattered image) or Cr-rich (darker in the backscattered image) carbides, or a combination of both. Previous published work ${ }^{[4-6]}$ has identified these as $\mathrm{M}_{6} \mathrm{C}$ and $\mathrm{M}_{23} \mathrm{C}_{6}$, respectively. The larger, blocky particles which are black in the backscattered image are titanium-rich carbonitrides, identified in the literature as $\operatorname{Ti}(\mathrm{C}, \mathrm{N})$. Identical particles were found in the $1 / 2$ inch plate, as shown in Figure 8.

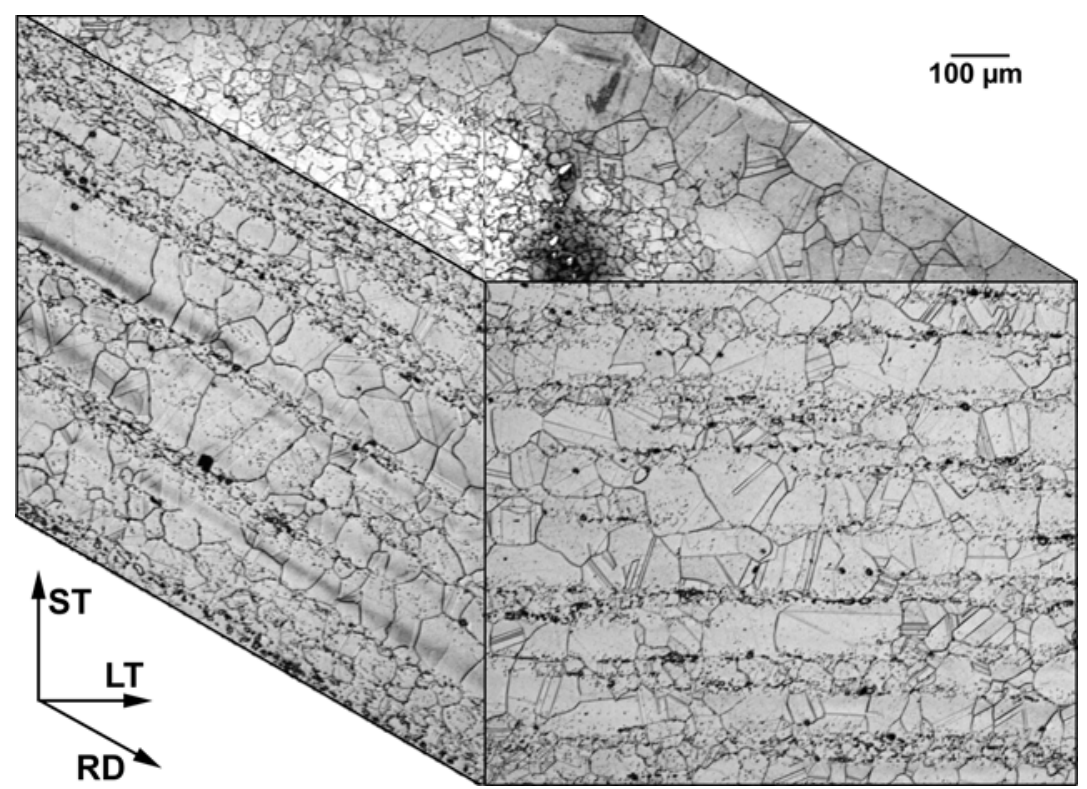

Figure 4. Three-dimensional montage of standard chemistry alloy 617 microstructure ( $3 / 4$ inch plate). 


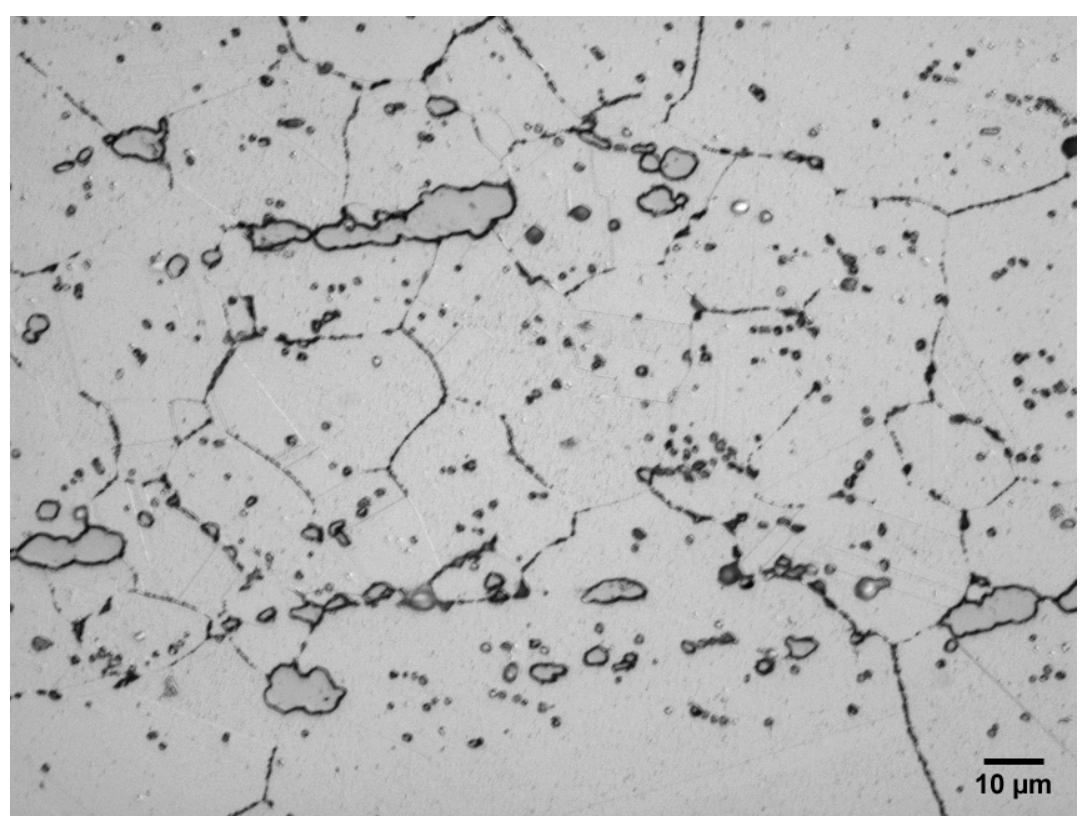

Figure 5. Stringers of coarse carbides in region of fine grains (3/4 inch plate).

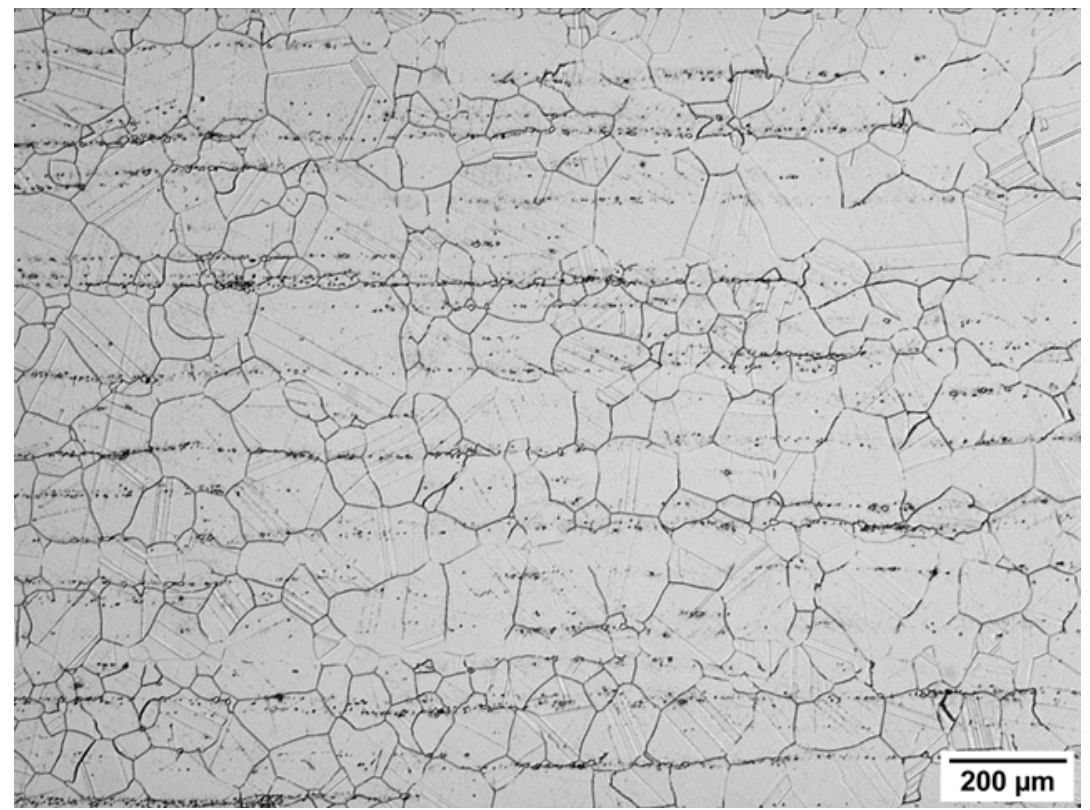

Figure 6. Microstructure of $1 / 2$ inch plate (section normal to long transverse direction). 
(A)

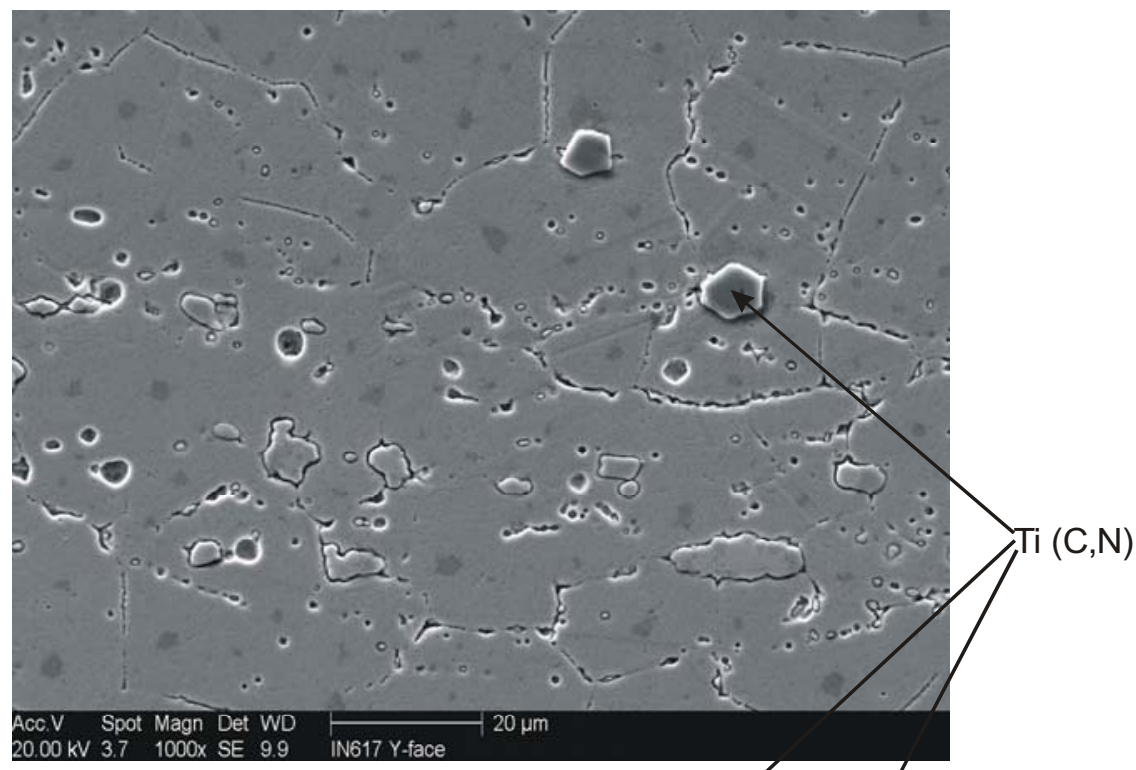

(B)

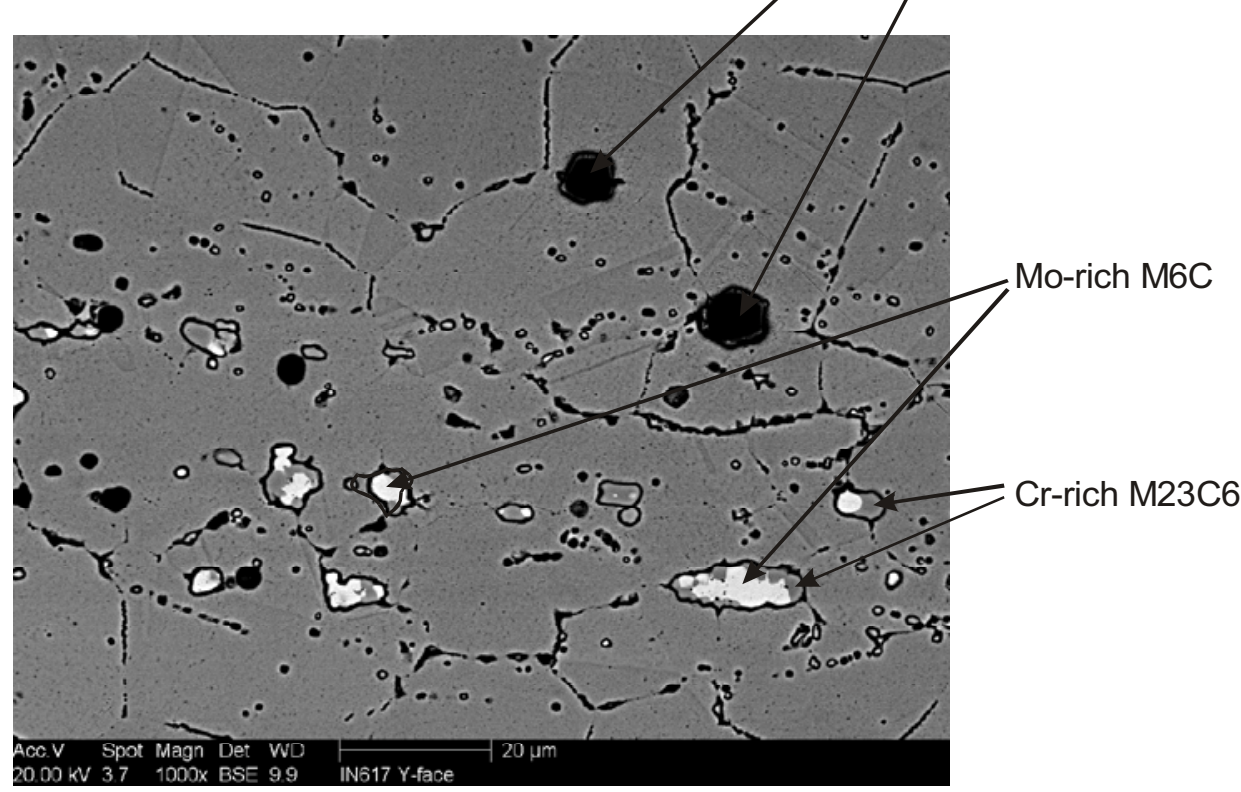

Figure 7. Secondary (a) and backscattered (b) electron images of carbides in the $3 / 4$ inch plate. 

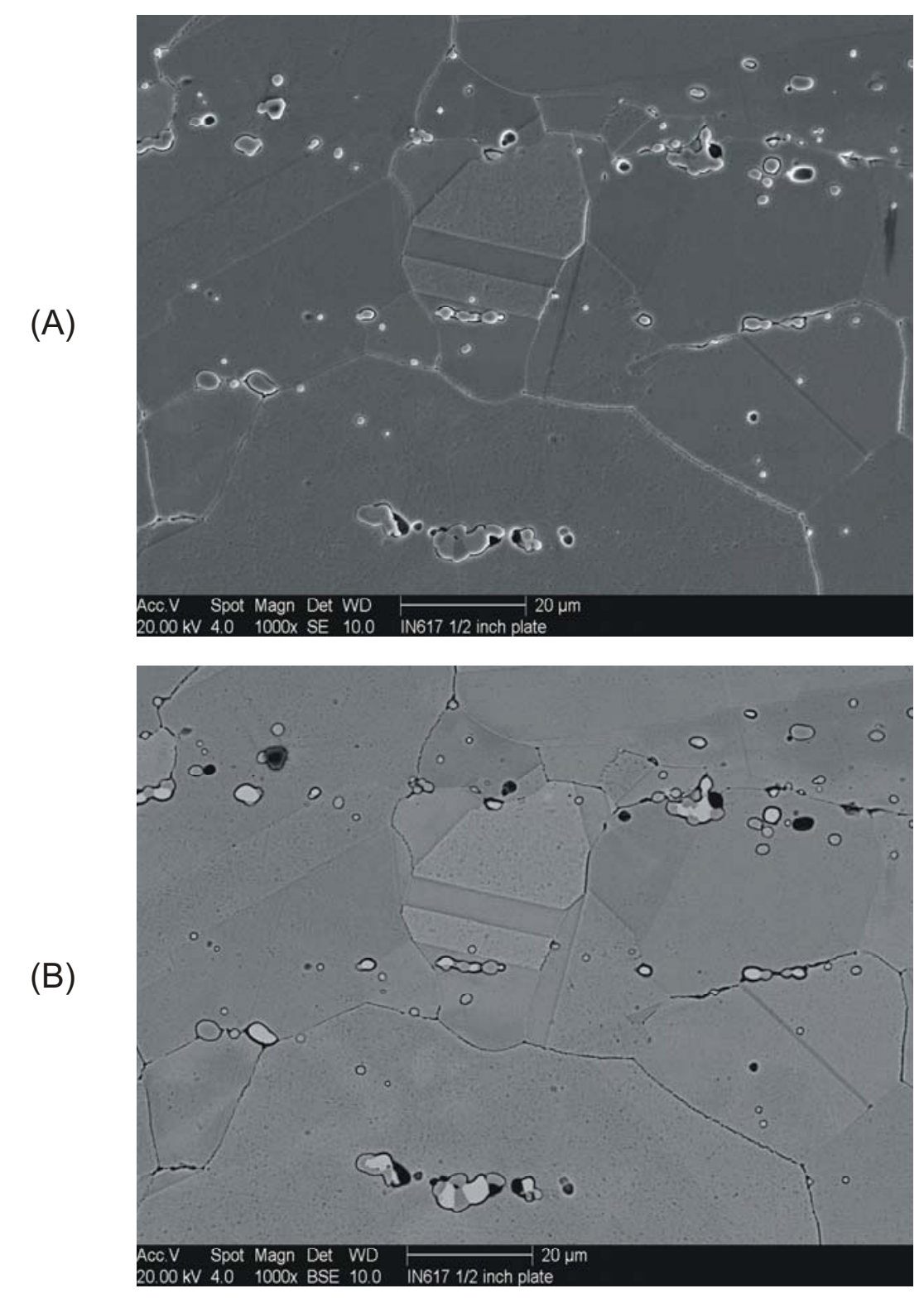

Figure 8 . Secondary (a) and backscattered (b) electron images of carbides in the $1 / 2$ inch plate.

\subsubsection{Tensile Properties}

Tensile properties for the base alloys and joints are listed in Table 3. The table lists mean values for conditions in which more than one test was performed; at least two identical specimens were tested for most conditions. The room temperature properties for both alloys agree with values reported on the certification sheets. The room temperature strength of the $3 / 4$ inch plate is slightly greater than the $1 / 2$ inch plate, a difference which likely results from the significant fraction of relatively fine grains present in the $3 / 4$ inch plate, as there are no significant chemistry differences between the two plates. The strength differences decrease with increasing temperature; at $1000^{\circ} \mathrm{C}$ the strengths of the two plates are essentially identical. The marked strain rate sensitivity of alloy 617 at elevated temperature is shown by the difference in yield and ultimate strength resulting from a three-fold increase in strain rate at $1000^{\circ} \mathrm{C}$. Good ductility is observed at all temperatures. 
Table 3. Tensile test results

\begin{tabular}{lcccccc}
\hline Material/Specimen & $\begin{array}{c}\text { Test } \\
\text { Temperature } \\
\left({ }^{\circ} \mathrm{C}\right)\end{array}$ & $\begin{array}{c}\text { Initial } \\
\text { Strain Rate } \\
(\text { sec-1) }\end{array}$ & $\begin{array}{c}0.2 \% \text { Yield } \\
\text { Stress } \\
(\mathrm{MPa})\end{array}$ & $\begin{array}{c}\text { UTS } \\
(\mathrm{MPa})\end{array}$ & $\begin{array}{c}\text { Ductility } \\
(\%)\end{array}$ & $\begin{array}{c}\text { RA } \\
(\%)\end{array}$ \\
\hline 1/2 Inch thick plate-01 & 25 & $1.00 \mathrm{E}-03$ & 363 & 807 & 62 & 50 \\
1/2 Inch thick plate-02 & 25 & $1.00 \mathrm{E}-03$ & 378 & 809 & 65 & 50 \\
3/4 Inch thick plate-01 & 25 & $1.00 \mathrm{E}-03$ & 404 & 885 & 55 & 54 \\
Fusion weld-01 & 25 & $3.00 \mathrm{E}-03$ & 496 & 850 & 38 & 44 \\
Fusion weld-02 & 25 & $3.00 \mathrm{E}-03$ & 487 & 878 & 38 & 36 \\
Fusion weld-03 & 25 & $3.00 \mathrm{E}-03$ & 487 & 858 & 40 & 40 \\
Braze butt joint-01 & 25 & $1.00 \mathrm{E}-03$ & 355 & 445 & 2 & 2 \\
Braze butt joint-02 & 25 & $1.00 \mathrm{E}-03$ & 353 & 494 & 3 & 2 \\
Braze butt joint-03 & 25 & $1.00 \mathrm{E}-03$ & 360 & 526 & 5 & 4 \\
Braze butt joint-04 & 25 & $1.00 \mathrm{E}-03$ & 361 & 490 & 4 & 4 \\
1/2 Inch thick plate-03 & 800 & $1.00 \mathrm{E}-03$ & 257 & 447 & 62 & 82 \\
3/4 Inch thick plate-02 & 800 & $1.00 \mathrm{E}-03$ & 285 & 453 & 57 & 69 \\
3/4 Inch thick plate-03 & 800 & $1.00 \mathrm{E}-03$ & 287 & 459 & 55 & 68 \\
Fusion weld-10 & 800 & $1.00 \mathrm{E}-03$ & 293 & 420 & 31 & 52 \\
Fusion weld-04 & 800 & $3.00 \mathrm{E}-03$ & 285 & 473 & 37 & 58 \\
Fusion weld-05 & 800 & $3.00 \mathrm{E}-03$ & 288 & 470 & 39 & 55 \\
Fusion weld-06 & 800 & $3.00 \mathrm{E}-03$ & 299 & 526 & 40 & 59 \\
Braze butt joint-05 & 800 & $1.00 \mathrm{E}-03$ & -- & 308 & 5 & 5 \\
Braze butt joint-06 & 800 & $1.00 \mathrm{E}-03$ & 226 & 310 & 6 & 5 \\
3/4 Inch thick plate-04 & 900 & $1.00 \mathrm{E}-03$ & 253 & 268 & 57 & 86 \\
3/4 Inch thick plate-05 & 900 & $1.00 \mathrm{E}-03$ & 254 & 259 & 66 & 87 \\
1/2 Inch thick plate-04 & 1000 & $1.00 \mathrm{E}-03$ & 146 & 154 & 67 & 84 \\
3/4 Inch thick plate-06 & 1000 & $1.00 \mathrm{E}-03$ & 143 & 150 & 59 & 87 \\
3/4 Inch thick plate-07 & 1000 & $1.00 \mathrm{E}-03$ & 146 & 155 & 62 & 90 \\
3/4 Inch thick plate-08 & 1000 & $3.00 \mathrm{E}-03$ & 179 & 186 & 61 & 94 \\
Fusion weld-11 & 1000 & $1.00 \mathrm{E}-03$ & 153 & 157 & 38 & 80 \\
Fusion weld-07 & 1000 & $3.00 \mathrm{E}-03$ & 173 & 177 & 42 & 83 \\
Fusion weld-08 & 1000 & $3.00 \mathrm{E}-03$ & 180 & 183 & 40 & 87 \\
Fusion weld-09 & 1000 & $3.00 \mathrm{E}-03$ & 180 & 180 & 43 & 85 \\
Braze butt joint-07 & 1000 & $1.00 \mathrm{E}-03$ & 141 & 141 & 1 & 1 \\
Braze butt joint-08 & 1000 & $1.00 \mathrm{E}-03$ & 136 & 136 & 1 & 1 \\
\hline
\end{tabular}

\subsection{Fusion Welds}

\subsubsection{Microstructure}

One of the two identical weldments produced is shown in Figure 9, and a macroscopic view of a polished and etched weld cross-section is shown in Figure 10. Both weldments appeared to be sound with no indication of porosity, hot cracking, or other defects. The weld fusion zone was comprised of large columnar grains with dendritic structure that was revealed as polishing relief. Typical fusion zone microstructures are shown in Figure 11. Fine second phase particles (likely carbides) were observed along grain boundaries and in interdendritic regions (Figure 12). Areas of fine equiaxed grains were observed (presumably recrystallized by the heat of subsequent weld passes), generally located in the 
center of the fusion zone. Figure 13 shows a typical fine grained area. The heat-affected zone (HAZ) of the weld was characterized by carbide dissolution and a small amount of grain growth. Figure 14 shows an overview of the fusion zone, the HAZ, and the base metal. A higher magnification view of the HAZ is shown in Figure 15.

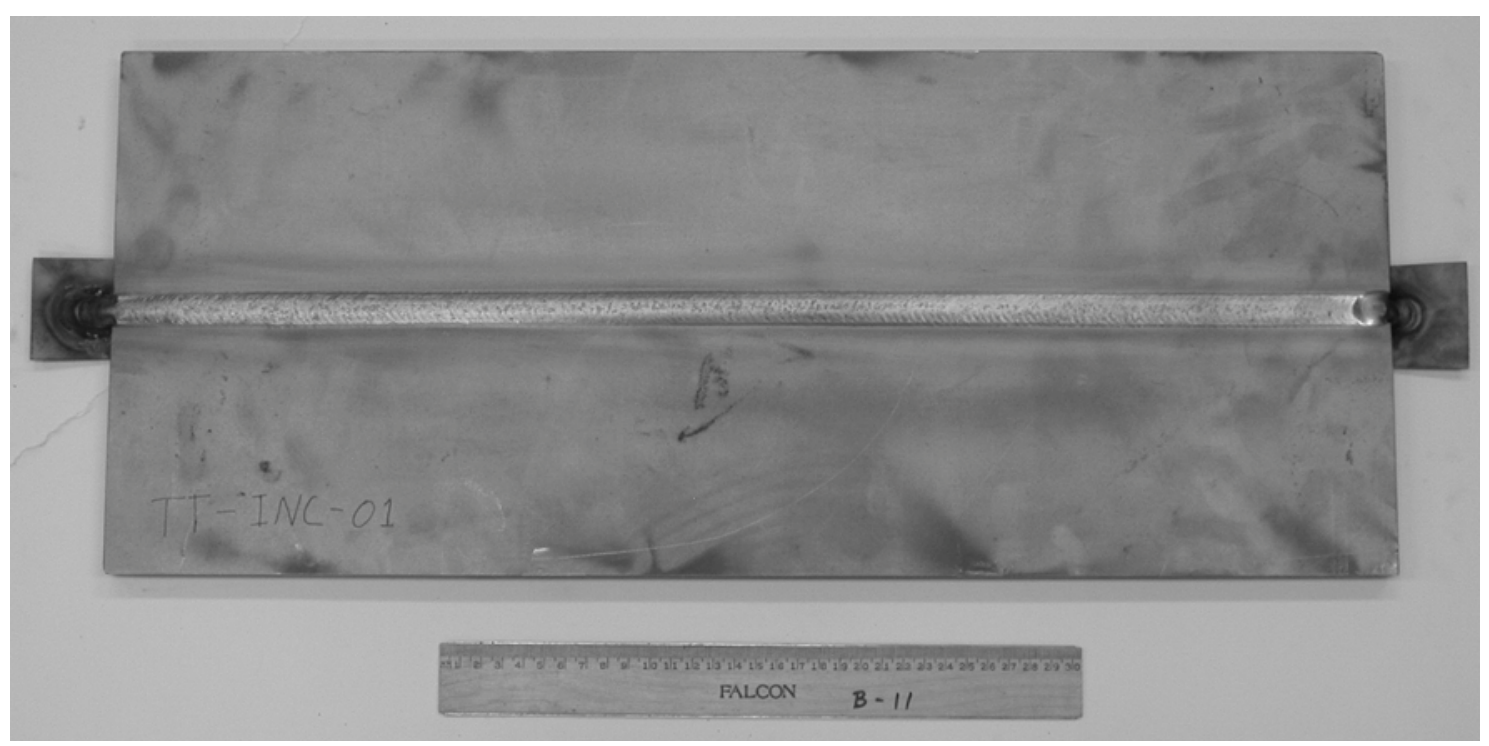

Figure 9. Fusion weld overview

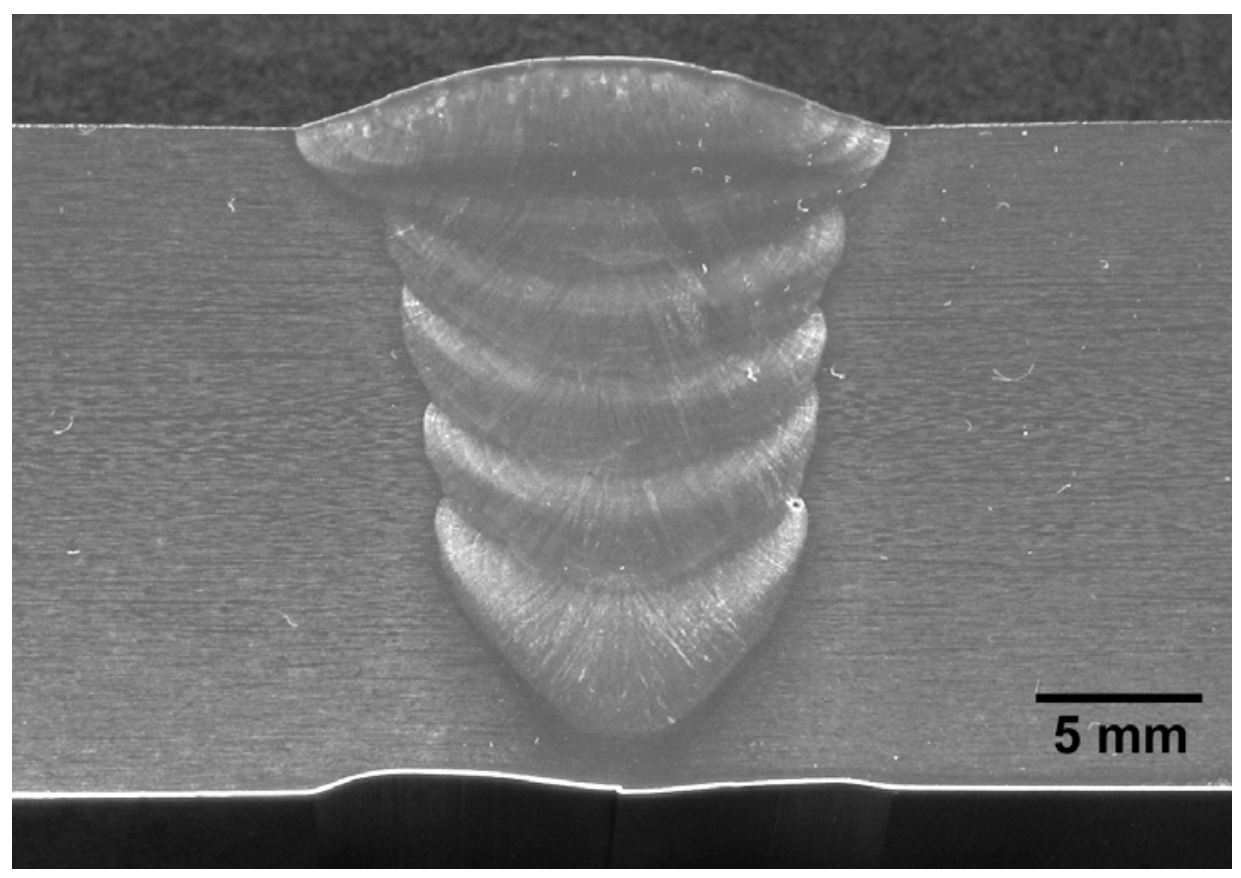

Figure 10. Polished and etched section of weldment. 

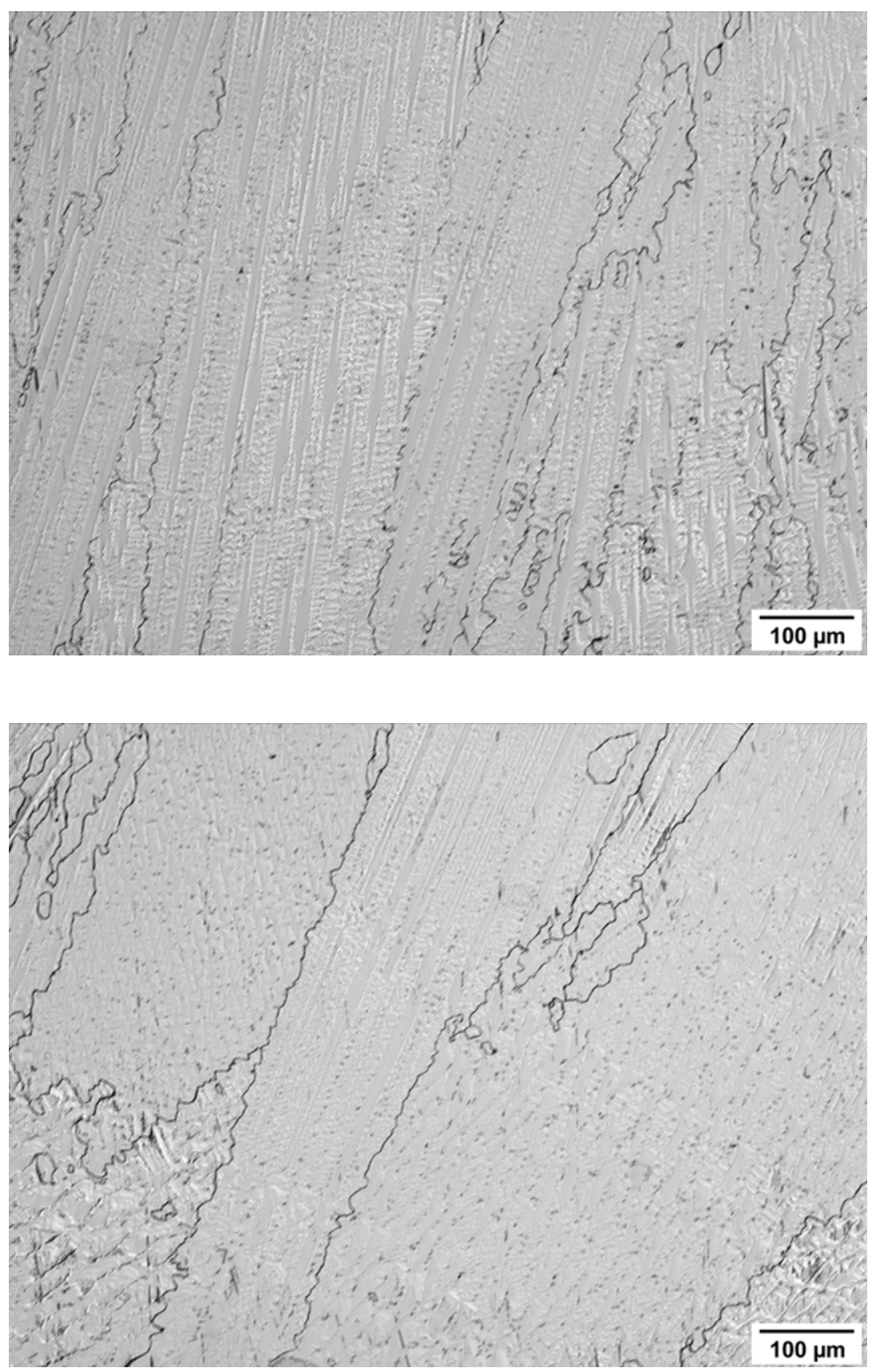

Figure 11. Typical fusion zone microstructures showing large columnar grains and dendritic structure. 


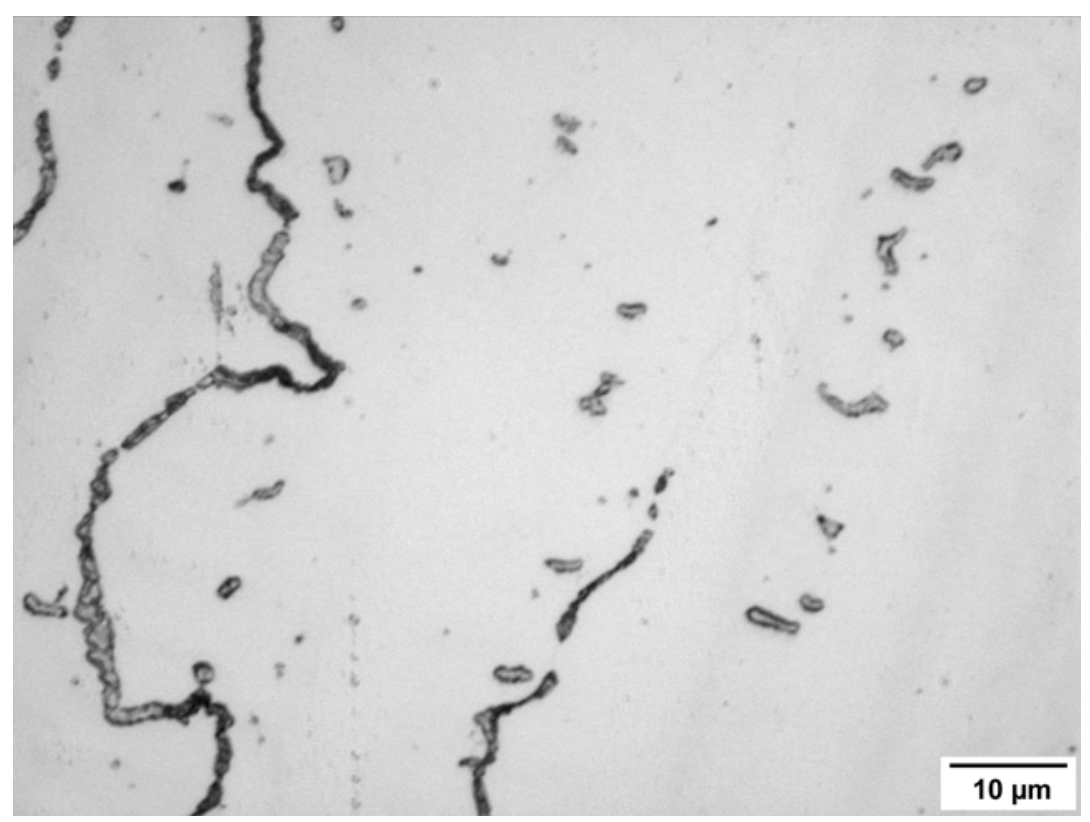

Figure 12. Close view of fusion zone microstructure showing second-phase particles along grain boundaries and in interdendritic regions.

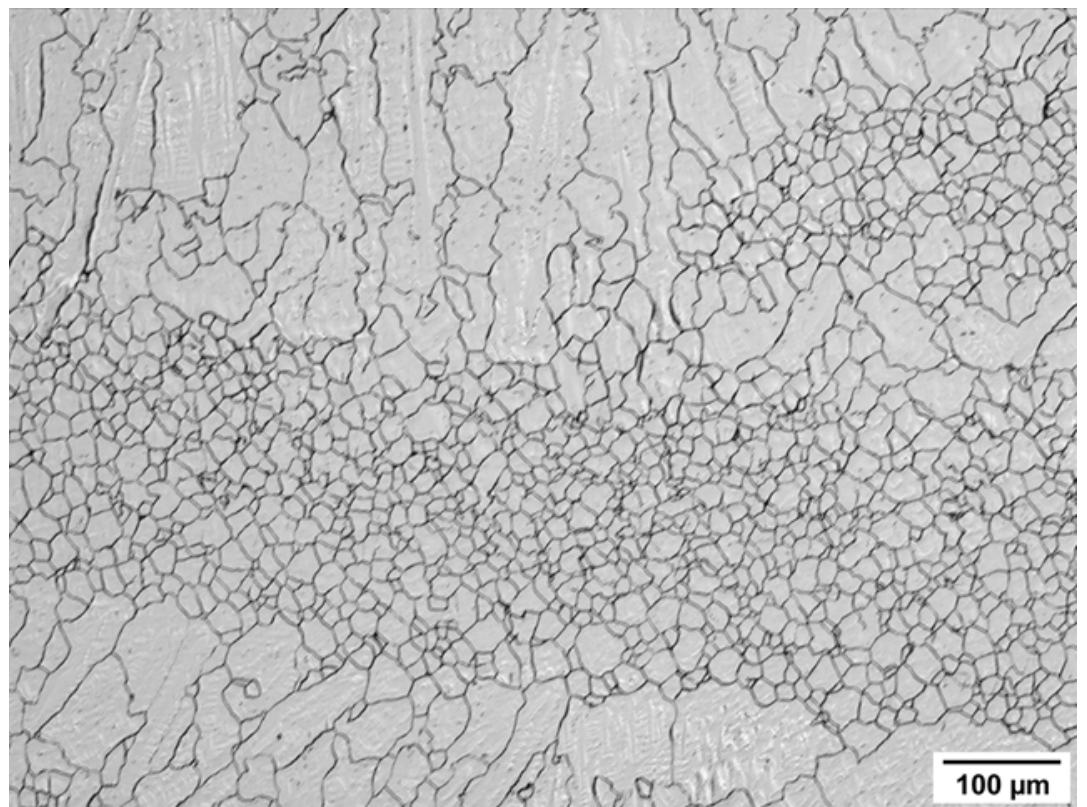

Figure 13. Typical area of fine recrystallized grains in the center of the weld fusion zone. 


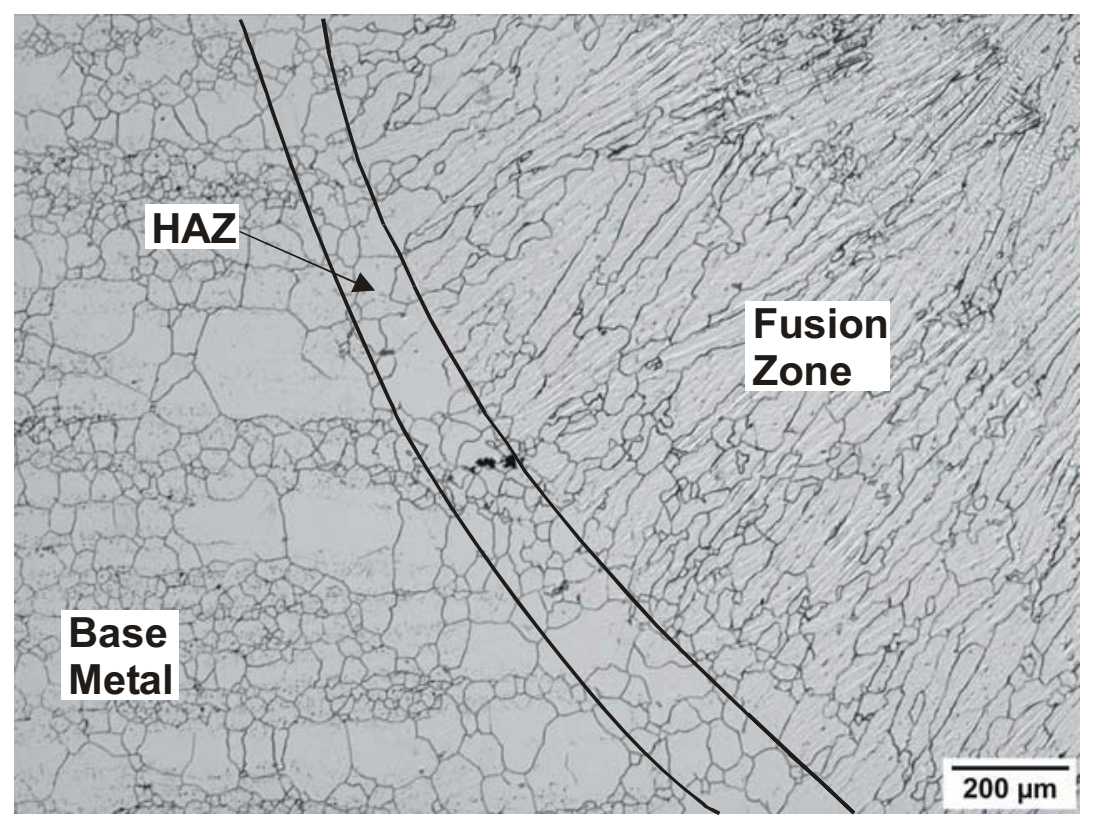

Figure 14. Overview of fusion zone - HAZ - base metal area.

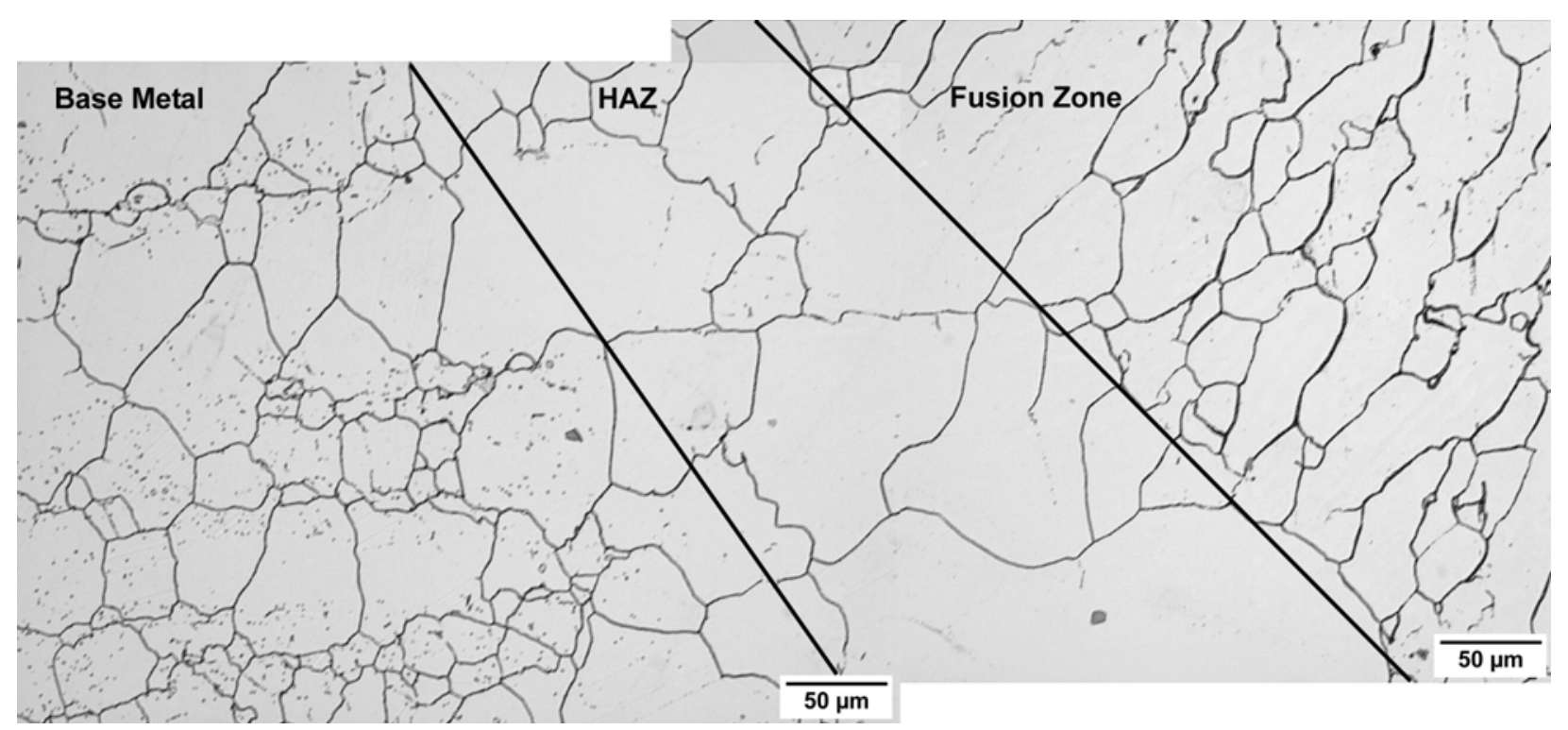

Figure 15. Close view of HAZ. 


\subsubsection{Tensile Properties}

Tensile properties measured on cross-weld specimens are listed in Table 3. The yield strength of the weldment specimens is higher than that of the parent metal at room temperature, but the ultimate tensile strength and ductilities are lower. The difference in strain rate $\left(3 \times 10^{-3} \mathrm{sec}^{-1}\right.$ for the welds versus $1 \times 10^{-3} \mathrm{sec}^{-1}$ for the parent metal) is not expected to affect properties at room temperature. Failure of weldment specimens occurred in roughly the center of the weld fusion zone. An overview of a polished and etched cross-section of a weldment specimen tested at room temperature is shown in Figure 16. The differences in strength and ductility are small, and may result from the differences in grain size, carbide size and distribution, and residual stresses. The yield strengths of the cross-weld specimens at elevated temperatures of 800 and $1000^{\circ} \mathrm{C}$ are again slightly greater than the parent metal at a strain rate $1 \times 10^{-3}$ $\mathrm{sec}^{-1}$, an increase likely due to the coarse grain size in the weld fusion zone. A yield strength difference was not observed at the higher strain rate $\left(3 \times 10^{-3} \mathrm{sec}^{-1}\right)$ at $1000^{\circ} \mathrm{C}$. The elevated temperature ductility of the cross-weld specimens was slightly lower than the parent metal, although failure consistently occurred in the parent metal (Figures 17 and 18). The ductility reduction again likely stems from the coarse grain size of the fusion zone - the coarse grains will be considerably more deformation-resistant than the finergrained parent metal and so will not contribute to overall specimen deformation, thus lowering the net measured ductility.

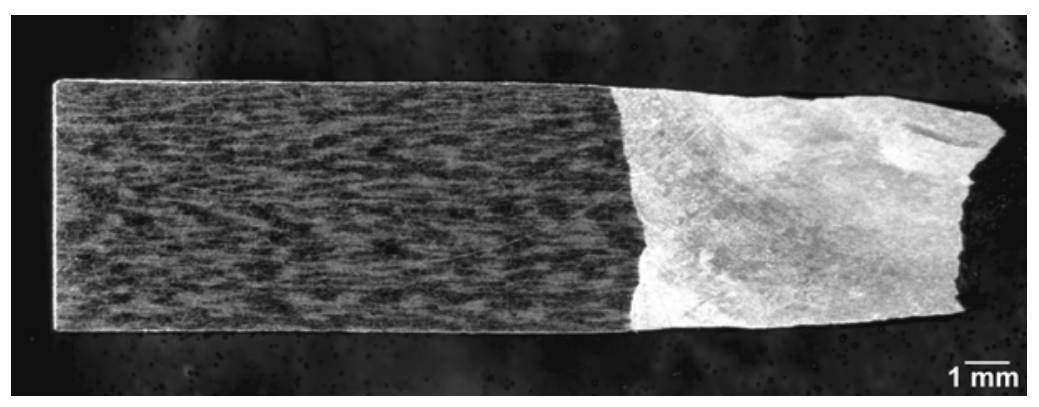

Figure 16. Polished and etched section of a cross-weld specimen tensile tested at room temperature. Weld fusion zone (bright) and fracture surface are on the right.

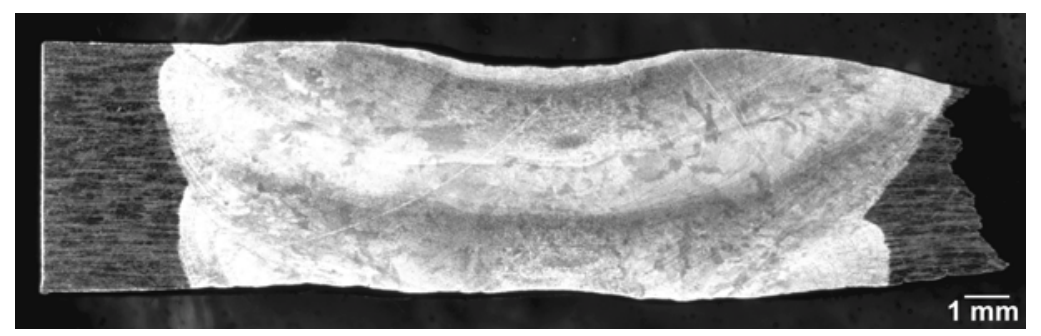

Figure 17. Polished and etched section of a cross-weld specimen tensile tested at $800^{\circ} \mathrm{C}$ at a strain rate of $3 \times 10^{-3} \mathrm{sec}^{-1}$. Weld fusion zone (bright) is in the center, fracture surface in the parent metal is on the right. 


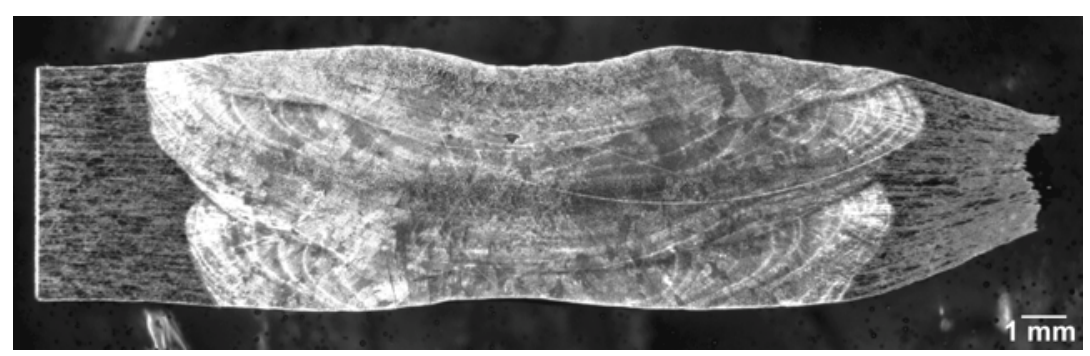

Figure 18. Polished and etched section of a cross-weld specimen tensile tested at $1000^{\circ} \mathrm{C}$ at a strain rate of $3 \times 10^{-3} \mathrm{sec}^{-1}$. Weld fusion zone (bright) is in the center, fracture surface in the parent metal is on the right.

\subsection{Braze Joints}

Although the braze joints received from Wall Colmonoy appeared to be sound upon initial examination, subsequent machining, non-destructive examination, and tensile testing revealed them to be poorly bonded. The poor bonding resulted from incomplete wetting of the braze alloy on one half of the joint. The scarf joints were particularly bad and tensile specimens could not be machined due to joint failure. Figure 19 shows two halves of a tensile test specimen blank that broke along the bond during machining. Good wetting occurred on the shiny half on the right, but very little braze metal wet the half on the left. Close examination of the dark surface revealed original machining marks from joint preparation.

Metallographic cross-sections of the braze joints also showed evidence of incomplete wetting. Figure 20 shows an area of the joint where wetting occurred on one side (bottom). The dark band is a gap between the two joint halves. Note that the top half does not show the extensive precipitation resulting from diffusion of $\mathrm{Si}$ and $\mathrm{B}$ into parent metal that is seen on the bottom half. A area of complete wetting and good bond is shown in Figure 21 for comparison. The sound braze joint is characterized by a coarsegrained bond area with large precipitates along grain boundaries in the center. The width of the coarsegrained area is approximately $230 \mu \mathrm{m}$. On each side of the joint there is extensive grain boundary precipitation (again due to diffusion of $\mathrm{Si}$ and $\mathrm{B}$ from the braze alloy into the parent metal); the total width of the joint, including these precipitates, is approximately $1 \mathrm{~mm}$. 


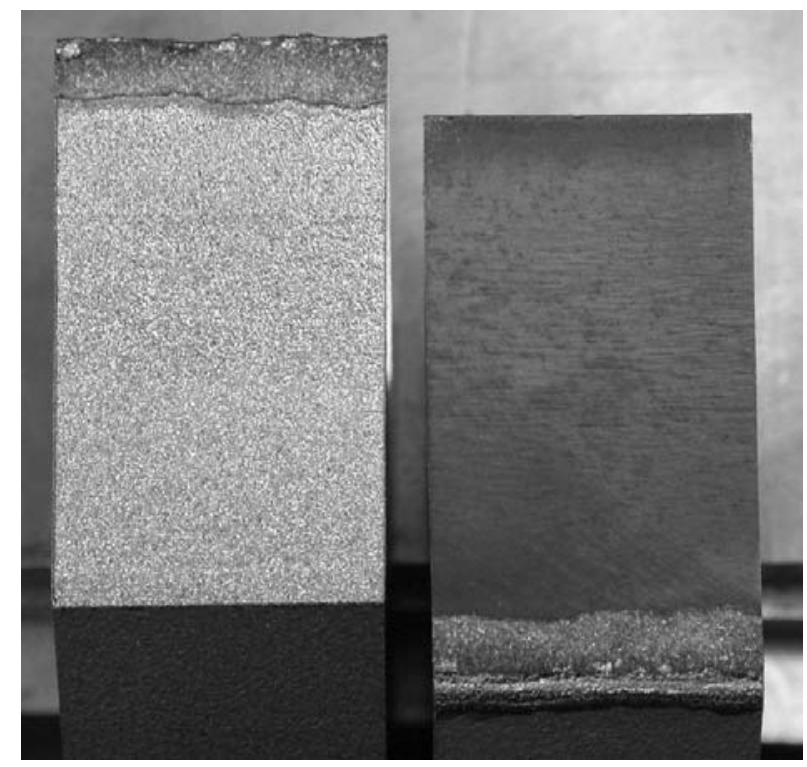

Figure 19. Mating halves of a braze scarf joint tensile specimen blank that failed along the bond.

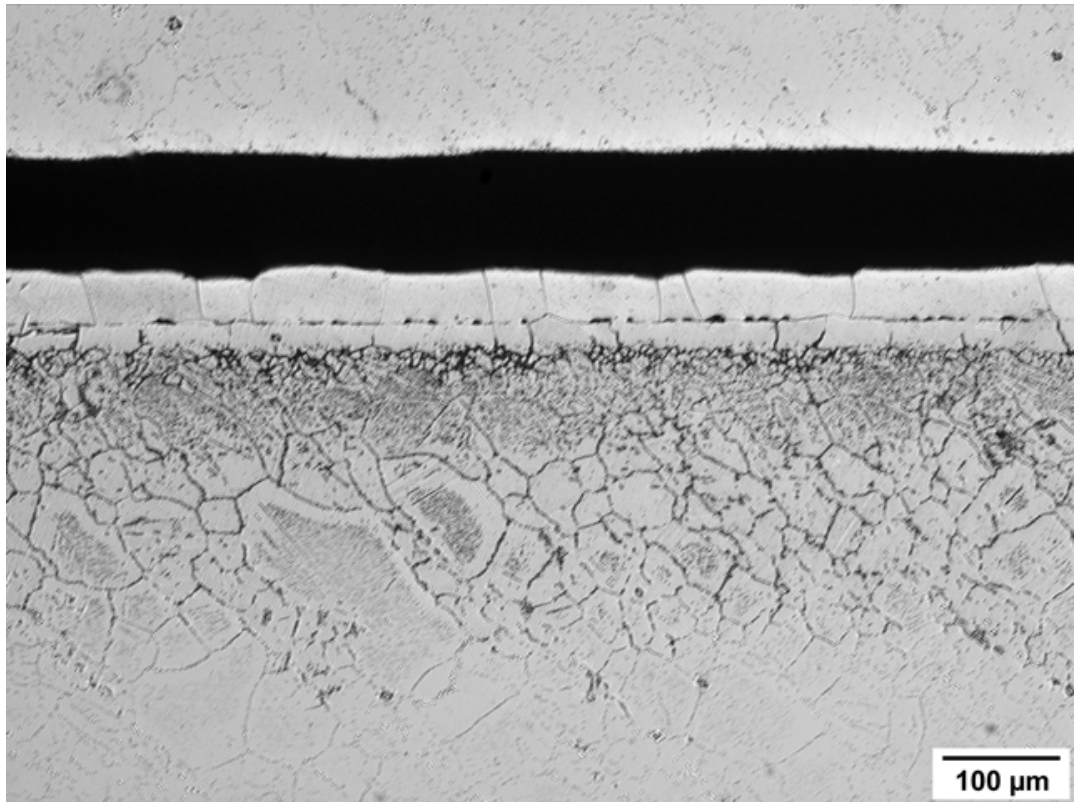

Figure 20. Etched metallographic cross-section of incomplete bond area. Wetted half of joint is on bottom, non-wetted half on top. 


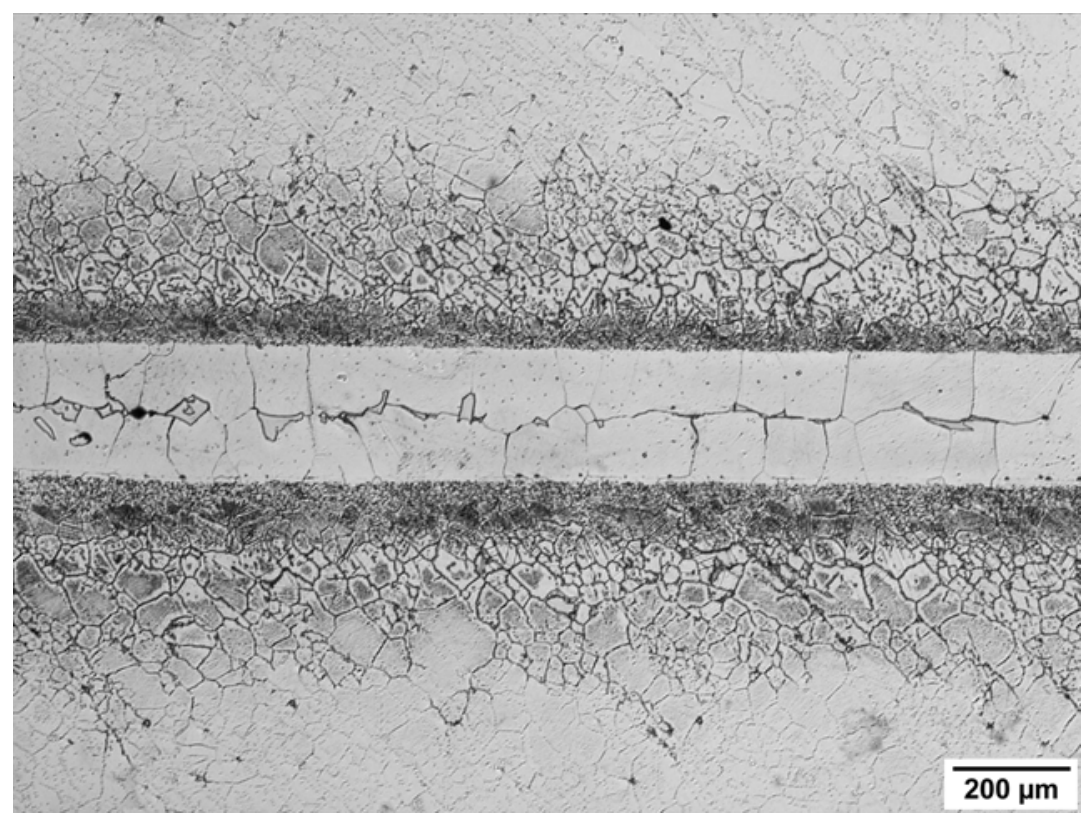

Figure 21. Etched metallographic cross-section of well-bonded area of braze joint.

Tensile specimens were successfully machined from the butt joints; tensile properties of cross-joint specimens are listed in Table 3. The strengths of the braze joints are much lower than the parent metal, and the ductilities are very poor. All specimens failed at the joint, and close examination of the fracture surfaces revealed incomplete bonding due to poor wetting. Figure 22 shows the fracture surface of a specimen tested at room temperature. The dark areas are incompletely bonded; machining marks from joint preparation are visible.

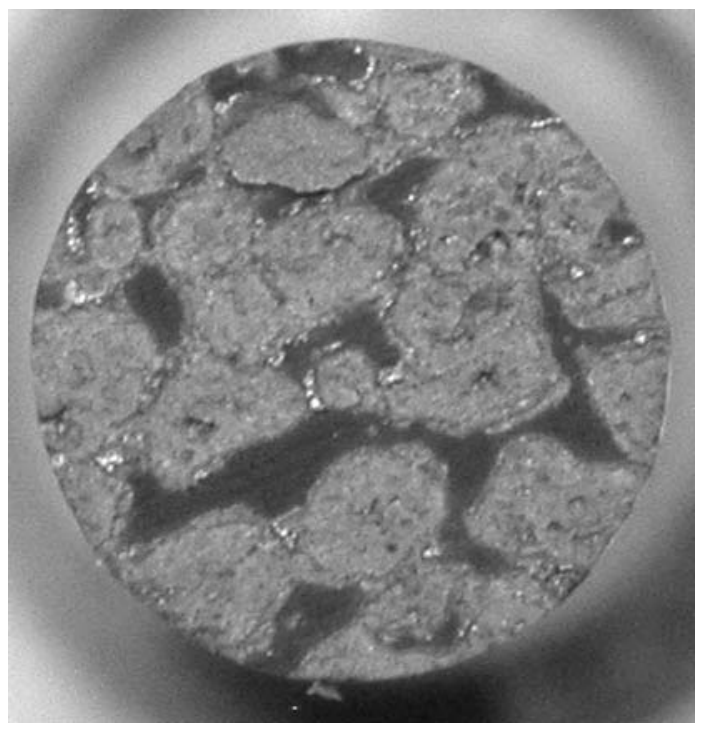

Figure 22. Fracture surface of incompletely-bonded braze joint tensile specimen tested at room temperature.

Wall Colmonoy, Inc., the brazing vendor, indicated that the likely cause of incomplete wetting was that the Al plus Ti content in alloy 617 was sufficiently high to form oxides which prevented wetting of the braze alloy, even in high vacuum. Cast Ni-base superalloys show similar behavior, and these alloys 
are electroplated with pure Ni prior to brazing to insure wetting. A second set of joint parts were sent to Wall Colmonoy and these have been re-brazed using the same conditions, but after application of a thin Ni plating layer. Characterization of the re-brazed joints is in progress.

\subsection{Diffusion Bonds}

Initial diffusion bonds were made at a relatively low stress of 3.5 MPa which proved to give incomplete bonding (shown in Figure 23), although grain growth was observed across the bondline. No difference was observed between as-machined and highly polished faying surfaces in this initial series. The next series used a higher initial stress level in conjunction with displacement rather than force control. The need for a pure Ni interlayer was also examined, by making bonds without the layer. Although apparently solid bonds were created, grain growth across the bondline generally did not occur at either 1120 or $1150^{\circ} \mathrm{C}$ bonding temperatures when the Ni interlayer was not used. Figures 24 and 25 show typical cross-sections of bonds made with and without a $\mathrm{Ni}$ interlayer at $1120^{\circ} \mathrm{C}$.

Given the success of these bonding conditions $\left(1120\right.$ or $1150^{\circ} \mathrm{C}$, Ni interlayer, $3 \mathrm{hr}$ hold $)$, a final attempt to refine the conditions was made by making bonds using a $2 \mathrm{hr}$ hold time instead of $3 \mathrm{hr}$, thereby shortening process time. As shown in Figure 26, gaps in the bondline were observed, and the original $\mathrm{Ni}$ interlayer was still prominent in some areas, indicating that the full $3 \mathrm{hr}$ hold time is needed to achieve quality bonds. Longer hold times have not been studied. Little effect of the bond temperature has been observed, except that some grain growth in the parent metal occurs during bonding at the higher temperature.

A final set of trial diffusion bonds were made using blanks machined from the $3 / 4$ inch plate; previous blanks had been machined from the $1 / 2$ inch plate. The initial stress was also slightly increased to improve bonding across the entire blank. Bonds created using the $3 / 4$ inch plate material were sound and essentially identical to the previous bonds. At the moment, an initial set of tensile test specimen blanks have been bonded and are waiting to be machined. These were bonded at $1150^{\circ} \mathrm{C}$ for $3 \mathrm{hrs}$ with a Ni interlayer in displacement control with an initial stress of $20 \mathrm{MPa}$.

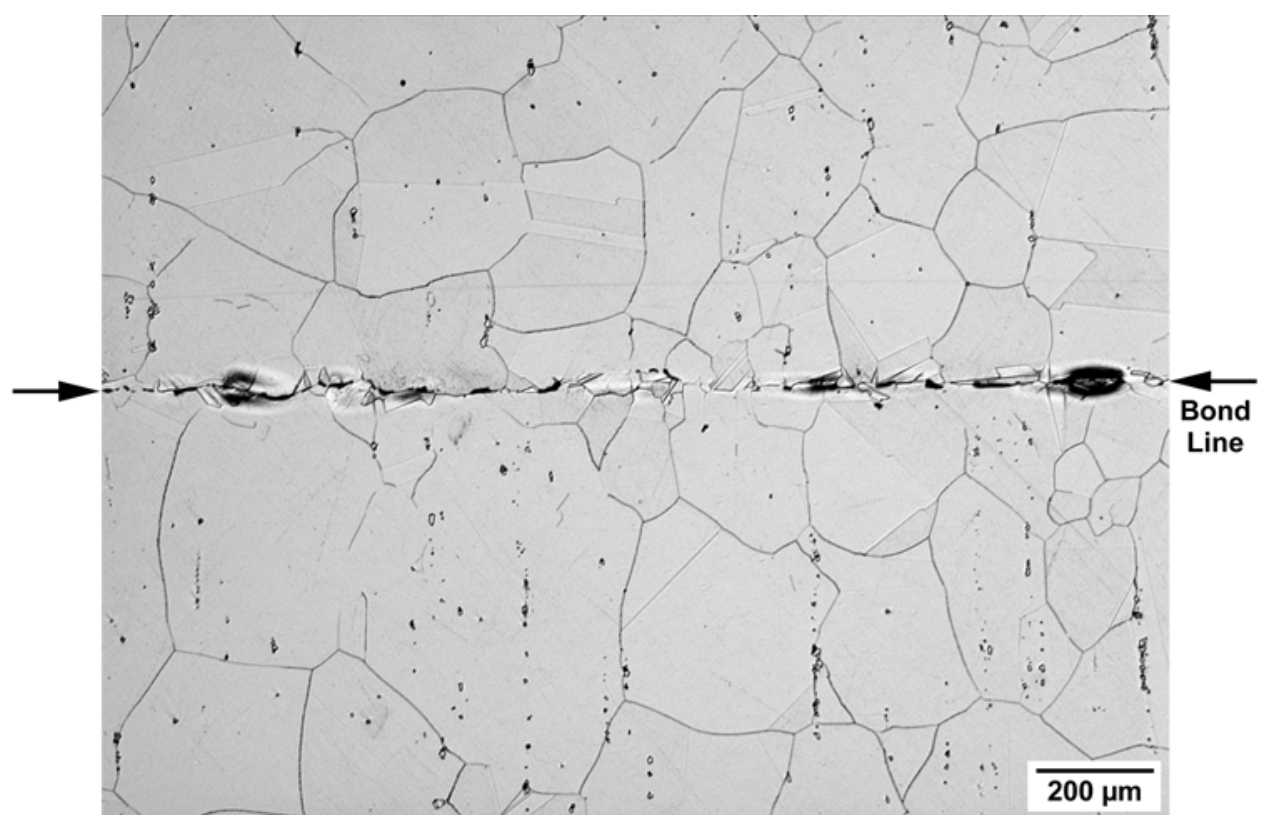

Figure 23. Etched cross-section of diffusion bond created at $1150^{\circ} \mathrm{C}$ and $3.5 \mathrm{MPa}$ with a 3 hour hold time and a $15 \mu \mathrm{m}$ thick Ni interlayer. Gaps are still present along the bondline. 


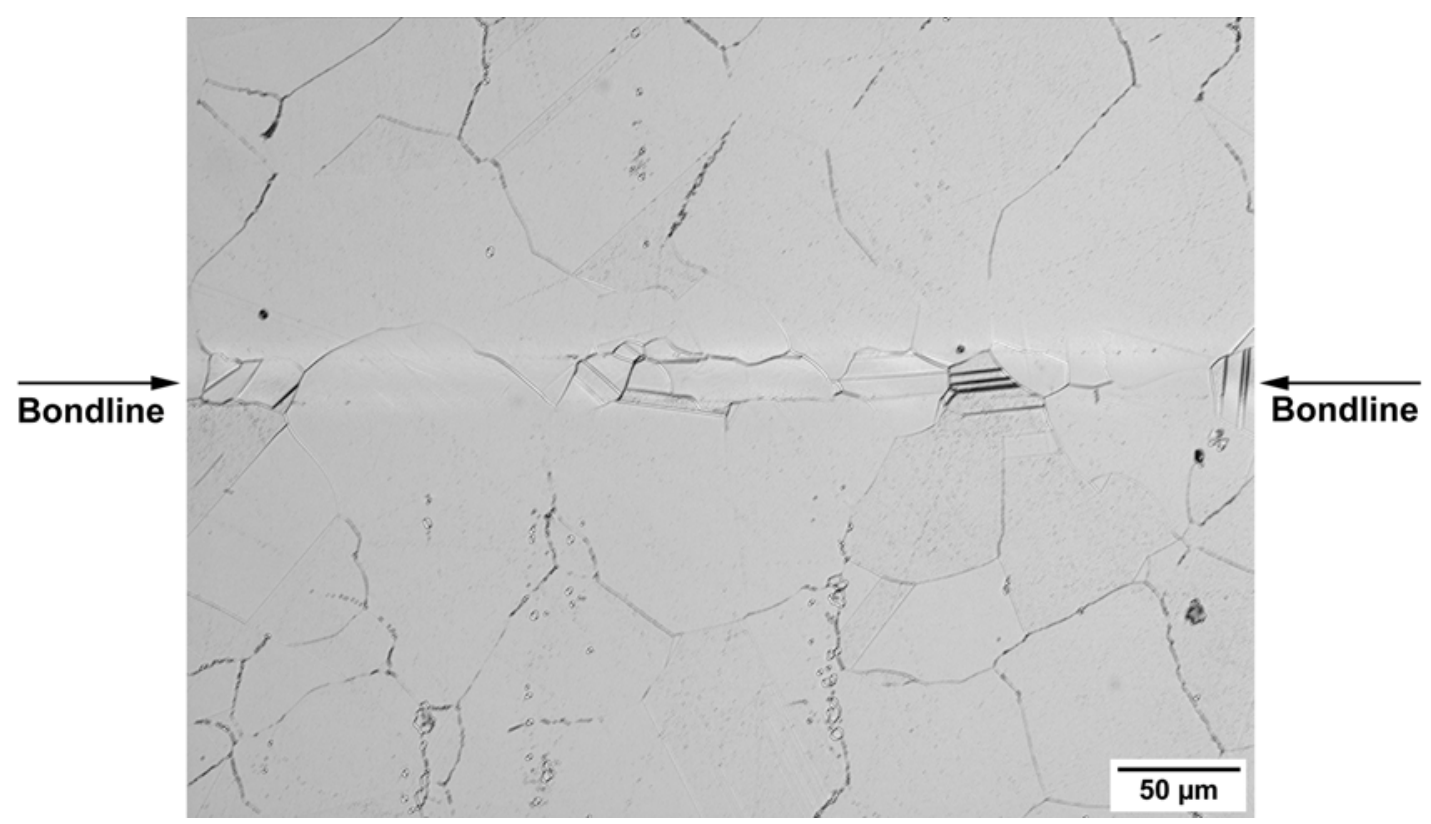

Figure 24. Etched cross-section of diffusion bond created at $1120^{\circ} \mathrm{C}$ and $15 \mathrm{MPa}$ initial stress (displacement control) with a 3 hour hold time and a $15 \mu \mathrm{m}$ thick Ni interlayer. Complete bonding with grain growth across the bondline was achieved.

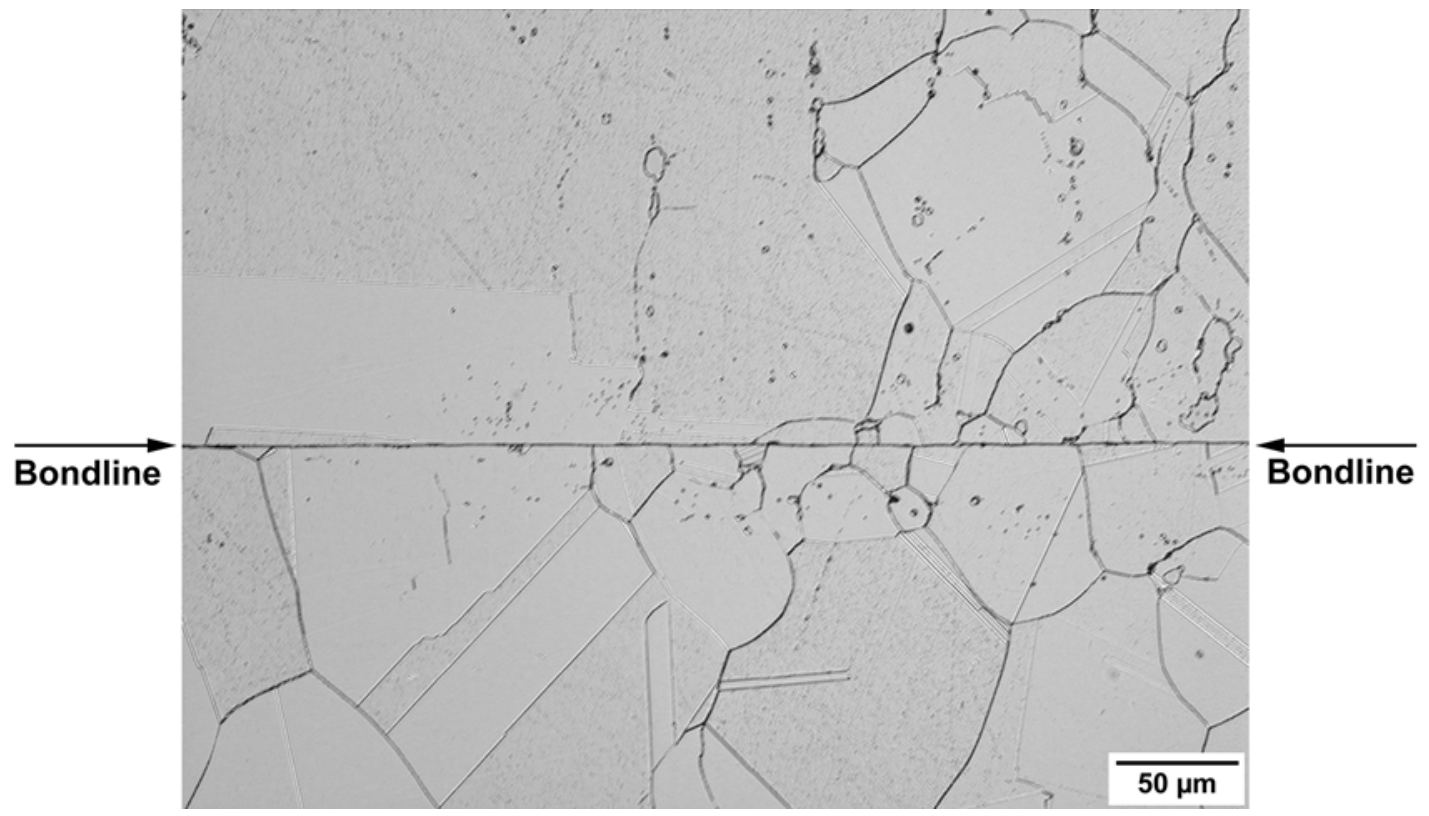

Figure 25. Etched cross-section of diffusion bond created at $1120^{\circ} \mathrm{C}$ and $15 \mathrm{MPa}$ initial stress (displacement control) with a 3 hour hold time and no interlayer. Complete bonding occurred but grain growth across the bondline did not occur. 


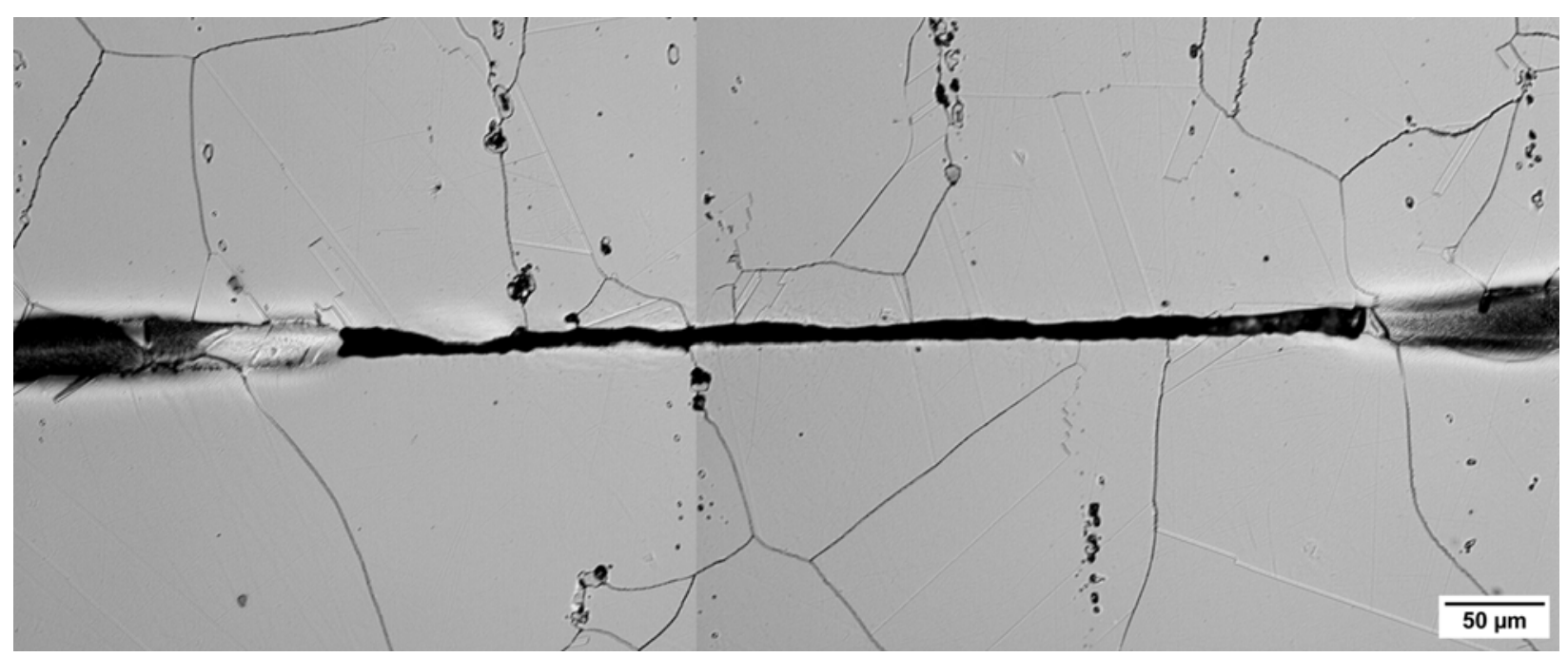

Figure 26. Example of incomplete bond area in diffusion bond created at $1150^{\circ} \mathrm{C}$ and $20 \mathrm{MPa}$ initial stress (displacement control) with a 2 hour hold time and $15 \mu \mathrm{m} \mathrm{Ni}$ interlayer.

\section{Discussion}

With the exception of the problem with braze joint wetting, the characteristics of the hightemperature alloy 617 joints have been as expected. Fusion welding of wrought, solid solution strengthened Ni-base alloys such as alloy 617 is well established and the weldment tensile properties are known to equal those of the parent metal. The longer-term objective of this project, however, is to study the creep-fatigue properties of these fusion welds, and this has been considerably less well studied. Diffusion bonding is also a well-established technique for Ni alloys, although it can be difficult due to their tendency to form tenacious oxides which prevent diffusion across the bondline. Use of pure Ni or $\mathrm{Ni}-\mathrm{Cr}$ interlayers is known to assist bondline diffusion ${ }^{[7]}$, and this was shown to be effective in the current study. A potential drawback of an interlayer is its weakness with respect to the base metal, since no strengthening elements are present other than those which diffuse in during the bonding cycle. Measurement of the concentration variation of key elements across the bondline is planned.

Tenacious oxide formation due to the $\mathrm{Al}$ and Ti content of alloy 617 is also believed to be the cause of the poor wetting behavior of the braze joints. Again, application of a layer of pure Ni to the bonding surfaces is expected to prevent oxide formation in the brazing thermal cycle and improve wetting behavior. Due to the high Cr, Si and B content of the braze alloy, the presence of a layer of pure Ni is not expected to present a strength issue, as it does in a diffusion bond. On the contrary, the high concentration of silicides and borides present after brazing may impair the ductility and creep-fatigue strength of the joint by acting as crack initiation sites.

Future work in this project will obviously include tensile testing of both diffusion bonds and braze joints with Ni electroplate; specimen machining is in progress. It is hoped to test diffusion bonds in both butt and scarf joint configurations, similar to the braze joints. Testing in shear with the scarf joint may be more aggressive for the diffusion bond due to the weak Ni interlayer; its weakening effect may be minimized in a butt joint configuration due to the constraint of the surrounding material. Creep-fatigue testing of fusion weld specimens will also soon be initiated.

A similar campaign of joint creation and characterization will be needed for other alloys; the two leading candidates are Haynes 230 and Hastelloy XR. Alloy 230 offers strength similar to alloy 617 but with less Co (a potential contamination source due to activation). Hastelloy XR is currently used in the 
Japanese HTTR and contains no Co. Given the multiplicity of alloys, joining techniques, and creepfatigue test conditions, however, it will certainly be necessary to eventually downselect alloys and joining techniques so that a substantial creep-fatigue database may be generated in a reasonable time on the most promising combinations.

\section{Conclusions}

Three types of high-temperature joints were created from alloy 617 parent metal: fusion welds, braze joints, and diffusion bonds. The microstructures of all joint and tensile properties of fusion welds and braze joints were characterized. The following conclusions were reached:

1. Sound fusion welds were created by the GTAW process with alloy 617 filler wire. Cross-weld tensile strengths were equal to or slightly greater than the parent metal at temperatures of 25,800 , and $1000^{\circ} \mathrm{C}$; ductilities of the joints were only slightly lower than the parent metal. Failure occurred in the weld fusion zone at room temperature and in the parent metal at elevated temperatures.

2. Incomplete wetting occurred in joints produced by vacuum brazing using AWS BNi-1 braze alloy, believed to due to tenacious Al and Ti oxide formation. Incompletely bonded butt joints showed relatively poor tensile properties. A second set of braze joints has been created with faying surfaces electroplated with pure Ni prior to brazing; characterization of these joints is in progress.

3. Conditions resulting in good diffusion bonds characterized by grain growth across the bondline and no porosity were determined: vacuum bonding at $1150^{\circ} \mathrm{C}$ for 3 hours with an initial uniaxial stress of $20 \mathrm{MPa}$ (constant ram displacement). A $15 \mu \mathrm{m}$ thick pure Ni interlayer was needed to achieve grain growth across the bondline. Tensile testing of diffusion bonds is in progress.

\section{References}

1. Next Generation Nuclear Plant Materials Research and Development Program Plan, Idaho National Engineering and Environmental Laboratory Report INEEL/EXT-04-02347, 2004.

2. K. Natesan, A. Purohit, and S.W. Tam, Materials Behavior in HTGR Environments, Argonne National Laboratory Report ANL-02/37, 2003.

3. V.N. Shah, S. Majumdar, and K. Natesan, Review and Assessment of Codes and Procedures for HTGR Components, Argonne National Laboratory Report ANL-02/36, 2002.

4. S. Kihara, J.B. Newkirk, A. Ohtomo, and Y. Saiga: Metall. Trans., 1980, vol. 11A, pp. 1019-31.

5. H. Kirchhofer, F. Schubert, and H. Nickel: Nucl. Technol., 1984, vol. 66, pp. 139-48.

6. W.L. Mankins, J.C. Hosier, and T.H. Bassford: Metall. Trans., 1974, vol. 5, pp. 2579-90.

7. M.M. Schwartz and D.F. Paulonis: in Welding Handbook, 7th Edition, Volume 3: Resistance and Solid-State Welding and Other Joining Processes, W.H. Kearns, Editor, American Welding Society, Miami, FL, 1980, pp. 311-36. 